\title{
Are There Managerial Practices Associated with Service Delivery Collaboration Success?: Evidence from British Crime and Disorder Reduction Partnerships
}

\section{Citation}

Kelman, Steven, Sounman Hong, and Irwin Turbitt. 2011. Are There Managerial Practices Associated with Service Delivery Collaboration Success?: Evidence from British Crime and Disorder Reduction Partnerships. HKS Faculty Research Working Paper Series RWP11-011, John F. Kennedy School of Government, Harvard University

\section{Published Version}

http://web.hks.harvard.edu/publications/workingpapers/citation.aspx?Publd=7625

\section{Permanent link}

http://nrs.harvard.edu/urn-3:HUL.InstRepos:4723208

\section{Terms of Use}

This article was downloaded from Harvard University's DASH repository, and is made available under the terms and conditions applicable to Other Posted Material, as set forth at http:// nrs.harvard.edu/urn-3:HUL.InstRepos:dash.current.terms-of-use\#LAA

\section{Share Your Story}

The Harvard community has made this article openly available.

Please share how this access benefits you. Submit a story. 


\section{Are There Managerial Practices Associated with Service Delivery Collaboration Success?: Evidence from British Crime and Disorder Reduction Partnerships Faculty Research Working Paper Series}

\section{Steven Kelman}

Harvard Kennedy School

\section{Sounman Hong}

Harvard Kennedy School

\section{Irwin Turbitt}

University of Warwick

\section{February 2011}

\section{RWP11-011}

The views expressed in the HKS Faculty Research Working Paper Series are those of the author(s) and do not necessarily reflect those of the John F. Kennedy School of Government or of Harvard University. Faculty Research Working Papers have not undergone formal review and approval. Such papers are included in this series to elicit feedback and to encourage debate on important public policy challenges. Copyright belongs to the author(s). Papers may be downloaded for personal use only. 


\title{
ARE THERE MANAGERIAL PRACTICES ASSOCIATED WITH SERVICE DELIVERY COLLABORATION SUCCESS?: EVIDENCE FROM BRITISH CRIME AND DISORDER REDUCTION PARTNERSHIPS
}

\author{
Steven Kelman \\ Harvard University \\ John F. Kennedy School of Government \\ Sounman Hong \\ Harvard University \\ John F. Kennedy School of Government \\ Irwin Turbitt \\ University of Warwick \\ Warwick Business School
}




\begin{abstract}
Little empirical work exists measuring if interagency collaborations delivering public services produce better outcomes, and none looking inside the black box at collaboration management practices. We examine whether there are collaboration management practices associated with improved performance of Crime and Disorder Reduction Partnerships, a crossagency collaboration in England and Wales. These exist in every local authority in England and Wales, so there are enough of them to permit quantitative analysis. And their aim is crime reduction, and crime data over time are available, allowing actual results (rather than perceptions or self-reports) to be analyzed longitudinally. We find that there are management practices associated with greater success at reducing crime, mostly exhibited through interaction effects such that the practice in question is effective in some circumstances but not others. Our findings support the arguments of those arguing that effective management of collaborations is associated with tools for managing any organization, not ones unique to managing collaborations: if you want to be a good collaboration manager, you should be a good manager, period.
\end{abstract}

KEYWORDS: INTERAGENCY COLLABORATION, PARTNERSHIPS, GENERIC MANAGEMENT 
There is perhaps no topic in public management research where the level of interest is so high and the level of evidence so low as for cross-boundary collaborations. Interorganizational collaboration is regularly presented as one of the central features of contemporary public management:

In the twenty-first century, interdependence and the salience of information have resulted in an environment where organizational and sectoral boundaries are more conceptual than actual, and collaborative managerial responses are required to complement, and in some cases even displace, bureaucratic processes. (Agranoff and McGuire 2003: 2; see also Abramson et al. 2006; Kettl 2008)

At the same time, many have noted the paucity of empirical evidence about whether, or when, or how, such collaborations improve public outcomes. "The literature on collaboration,” write O’Leary et al. (2009: 6; see also Dickinson and Glasby 2010) “is often celebratory and only rarely cautious.” Regarding environmental collaborations, Koontz and Thomas (2006: 111, emphasis in original) write, “[T]he most crucial question in collaborative environment management remains unanswered and, all too often, unasked: To what extent does collaboration lead to improved environmental outcomes?” Regarding health collaborations, Lasker, Weiss, and Miller 2001: 181) state, "Funders and partners assume that collaboration will be more effective than efforts planned and carried out by a single organization or sector, yet there is little evidence that collaboration has improved health status or health systems in communities.” Geddes (2008: 204) notes that in the U.K., the empirical location for this research, "Partnership has now been an

\footnotetext{
* The authors would like to thank Perri 6, Jean Hartley, Michael McGuire, John Friedman, Anthony Bertelli, and especially Alberto Abadie and Joshua Goodman, for helpful comments and advice. Valuable work constructing our dataset was provided by Ava Tramer, Whitney Afonso, Gordon Liao, Bingru Wang, and IFF Research. The authors would also like to thank the Roy and Lila Ash Center for Democratic Governance and Innovation at the Harvard Kennedy School for generous grants in support of this research.
} 
integral part of urban and regional development since at least the early 1990s, but this orthodoxy continues to conceal concerns about the effectiveness of partnerships from the point of view of policy-makers and practitioners.” With some irony, Huxham and Vangen (2005: 60) observe that "reports of unmitigated [collaboration] success are not common." This paper presents empirical evidence about whether there are management practices associated with the effectiveness of an interagency collaboration in England and Wales, called Crime and Disorder Reduction Partnerships (CDRP's), in reducing crime. CDRP's were established by the Crime and Disorder Act of 1998 and required in every local government (called “local authority”) area in England and Wales. ${ }^{1}$ CDRP's are a collaboration consisting mostly of government organizations - the police (which are organizationally autonomous from local government), the Probation Service (a central government organization working mostly with recently released prisoners), the Youth Offending Service (also a central government organization dealing with young people at risk of crime), the Fire Service (also an autonomous local organization), local government service organizations (such as street lighting, parks, and inspectional services), and a number of other organizations, often including the voluntary sector. ${ }^{2}$ Partnerships such as CDRP's have been common in the U.K. (Sullivan and Skelcher 2002; 6 et al. 2002), where they have often been conceptualized (Lowndes and Skelcher 1998; Glendinning, Powell, and Rummery, 2002) as an alternative to both central bureaucracies and markets as a governance method. Sullivan and Skelcher report (Ibid.: 26-27) that around the beginning of the millennium, there were approximately 5500 local or regional partnership bodies in the U.K. that were "stimulated or directly

\footnotetext{
1 A CDRP's boundaries are co-terminous with the boundaries of the local authority.

2 CDRP's are not required to include organizations dealing with social problems such as employment.
} 
created by government," in sixty different policy domains (such as local economic development, health, and education), with three-quarters of their funding provided by the national government; during 1999 the word "partnership” was used 6197 times in Parliament, compared to 38 times a decade earlier (Ling 2002). One recent textbook on local government in the U.K. (Wilson and Game 2006: 18) states that “[p]artnership working has become a central feature of today's local government.”

There are, of course, different kinds of interorganizational collaborations, with different purposes. Some are entirely inside the public sector, while others involve public organizations working with private ones (Agranoff 2007; Klijn 2008; Sandfort and Milward 2008). CDRP's are one kind. They are, first, mostly inside government, rather than public-private partnerships. Second, their purpose is service delivery, rather than simply information-sharing among organizations with overlapping missions or conflict resolution among contending parties. Other examples involving these two features would be multiagency case management for poor families, or joint agency efforts to manage ecosystems or identify terrorists (Gans and Horton 1975; Thomas 2003; Zegart 2009).

We know of only a few empirical papers trying to measure if interagency collaborations delivering public services produce better outcomes, and none looking inside the black box at collaboration management practices. Jennings and Ewalt (1998) find a modest relationship between degree of "administrative coordination" in state-level job training programs (involving several agencies, and often private participants) and some, but not all, measures of job success performance. Ryu and Rainey (2009) compare job training programs with one-stop shopping capabilities with those without, concluding the former produce somewhat better outcomes. Page (2003) notes that outcomes for 
children's services in Georgia and Vermont improved subsequent to interagency collaborations, but points out that the improvement corresponded to a major national economic upswing; he also cites a consulting study for Georgia concluding that introduction of collaboration measures was followed by improvements. Just about all the other few discussions using performance as a dependent variable (e.g. Chen 2010) employ self-reported perceptions of participants as success measures.

CDRP's provide a rare opportunity for empirical research on whether there ways interagency collaborations are managed and led that are associated with improved social outcomes. First, by statute they exist -- with similar memberships, responsibilities, and powers -- in every local authority in England and Wales, ${ }^{3}$ so there are enough of them to permit quantitative analysis. Second, their aim is crime reduction, and crime data over time are available at the local authority level, allowing actual results (rather than perceptions or self-reports) to be analyzed. This combination is seldom available for research on collaborations - indeed, it is seldom available in public management research in general. Since CDRP's exist in all local authorities, our research strategy will not be to compare places with collaborations and those without, but rather to exploit variation in management practices across CDRP's to see whether any are associated with improved crime performance. Thus, we seek to look inside the CDRP black box.

At least compared with many collaborations, CDRP’s have significant capacity, making them a best-case scenario for success, at least in the world of interagency collaboration as it currently exists. They are managed through what Provan and Milward 1995 call a "network administrative organization" - a dedicated unit, with its own staff and managers, separate from constituent agencies in the CDRP. CDRP's also frequently

3 Initially there were 376 of them, although the number has been reduced to 372 by mergers. 
organize cross-agency initiatives the CDRP runs itself. By statute, the CDRP, not any component agency, is responsible for recommending so-called “anti-social behavior orders,” restrictions aimed at disruptive people (mostly youth) establishing individualized limitations on people with whom or streets where they may congregate. Some CDRP's also run "warden” programs; wardens, who have no arrest powers, patrol neighborhoods to provide additional official presence and learn more about crime problems. Other examples of CDRP-run programs include collaborations between police and local regulatory agencies against illegal liquor purchases or pawnshops dealing in fenced goods, efforts to put gates in alleyways to inhibit entry of burglars, and police and probation programs to watch "prolific and persistent” offenders. CDRP's had also, at the end of the period for which we gather data, been in existence for almost a decade.

\section{HYPOTHESES}

There are many reasons why it is difficult to get collaborations to work well different cultures and priorities among participant organizations, worry about time taken away from an organization's main work, fears of being held accountable for actions not under an individual organization's control (see Bardach 1998 for a summary of these challenges). Furthermore, compared to both hierarchies and markets, collaborations have fewer tools available to influence the behavior of participants (Williamson 1975; Powell 1990). Hence the proposition of Bryson and Crosby (2008): “The normal expectation ought to be that [collaboration] success will be very difficult to achieve.”

The literature on managing collaborations is filled with statements about practices purported to be associated with success, with little or no evidence to establish a relationship (Agranoff 2007; Hibbert, Huxham, and Ring 2008). Furthermore, the 
literature is laden with platitudes: "What might be surprising to practitioners looking for new insights is just how few specific and practical 'tricks' are actually offered that are not at some level common sense” (6 et al. 2002: 128); one book, called Making Collaboration Work (Wondolleck and Yaffie 2000: 123, 149, 159), for example, recommends collaboration managers adopt “a flexible, positive attitude,” “commitment to a collaborative process," and that they work at "fostering understanding."

A useful way to categorize managerial techniques for collaborations is to distinguish between those associated with management in general (originally developed for single, hierarchical organizations) and those of collaborative management in particular (unique to or at least specially characteristic of collaborations). The literature has focused considerably more on techniques of the latter sort. The Mattessich and Monsey (1992) literature review, for example, included no studies mentioning tools of management in general, possibly because these had been studied and found to be unimportant, but more likely because they hadn’t been tested at all.

The lack of attention to use of techniques of management in general relates, of course, to the relatively limited ability of collaboration managers to use them. "The most obvious difference between a confederation of organizations and a single organization is that confederations lack strong central authority.” (Litwak and Rothman 1970: 137) Generally, participation is voluntary. Even in CDRP's, where formal participation of some agencies is legally mandated, engagement cannot be commanded. Collaborations lack formal authority to assign and direct work, except for a partnership's own staff, that is the distinguishing hallmark of the employment relationship in a hierarchy (Barnard 1938; Williamson 1975), as well as tools associated with human-resource management 
(hiring, promotion, firing), though these are generally weaker in government than firms. Collaborations seldom sign binding contracts with member organizations, which might specify commitments in exchange for something. Thus, “[I]nterorganizational analysis will frequently use, as explanatory variables, elements that are disregarded or minimized in intraorganizational studies.” (Litwak and Hylton 1962: 398)

There is a minority strand in the literature. Thatcher (2004: 93) disagrees with the view that collaborations "are radically different from conventional organizations," referring to them as "inchoate hierarchies.” Bardach (1998: 21) argues that “interorganizational collaborative capacity is very much like an organization in its own right.” The empirical work of Milward and Provan (1995; see also Provan and Kenis 2008) argues that more centralized networks tend to perform better. Alternatively, given the presence in single organizations of stovepipes with distinct cultures and often-weak controls across them, of the relatively weaker strength of hierarchical tools in government compared to firms, and of non-hierarchical ways of leading that have been promoted in a single-organizational context, one might argue that hierarchies in government share features of collaborations (Page 2003; McGuire 2006). Rodrigeuz, Langley, and Beland (2007) argue collaborations are more likely to succeed if they mix hierarchical and other tools. Moynihan (2005) notes that successful emergency management involves a mixture of collaboration and command-and-control.

In particular, we note a distinction between "front-end" tools of hierarchical management - such as hiring, task assignment, and work direction - and "back-end" ones such as performance measurement, followup, and promotion/dismissal. When thinking about hierarchical management, people often think mostly about front-end tools, which 
are those collaborations don't have available. However, collaborations do have available many back-end tools, albeit not promotion/dismissal (keeping in mind that hierarchies in government seldom in practice have dismissal tools either). Furthermore, some collaborations have an ability to access external funds, and also the support of managers outside the collaboration who do have hierarchical authority over collaboration members; gaining access to such resources may increase a collaboration's hierarchical authority by giving the it incentives it can use to induce member cooperation. Taken together, the availability to collaborations of some hierarchical tools may thus be underestimated. Since the tools potentially available to collaborations are a subset of hierarchical tools as a whole, we will together call these "hierarchy light."

Some of the most-common management tools hypothesized to be associated with collaboration success appear below, 15 in all. ${ }^{4}$ We hypothesize that prioritizing the practice, compared with other tools the manager could use, reduces crime. Each practice may be seen as a "treatment"; we look at the effect of each on crime. The first group are associated with collaborative management in particular. The second are tools of management in general. The third -- managing outward -- is discussed widely in literature on managing single organizations in government (Moore 1995; Heymann 1987), and thus are tools of public management in general.

(1) Promoting voluntary cooperation

a. Building Trust: The view that collaborations are very different from hierarchies tends to be associated with the suggestion that building trust is a central

\footnotetext{
${ }^{4}$ These are taken from literature discussing not only the kind of interagency service-delivery collaborations most similar to CDRP's, but also from discussions of other kinds of collaborations such as information-sharing networks inside government or cross-sectoral collaborations. We also undertook exploratory in-person interviews with CDRP managers where we asked them to talk about their jobs.
} 
management priority, since this is needed to overcome distrust that hinders voluntary cooperation (Agranoff and McGuire 2001; Thatcher 2004). Such distrust in turn grows from different cultures and predominant missions among participating agencies, where each organization can easily come to see the others in "outgroup” terms, subject to negative stereotyping (Sherif et al 1961; Tajfel et al 1971; Turner et al 1987).

For CDRP's, the major cultural clashes would be between police on the one hand, and probation, drug treatment, and at-risk youth agencies on the other, where police often see the latter as "pro-offender” and non-police groups often see police as ignoring social causes of crime. Until the mid-1990's U.K. probation officers were required to have social work degrees (Nash 2004). Those working with young addicts "see part of their role as client advocacy and support” and don't even want to share information with youth offending agencies (Minkes and Raynor 2005). In one survey from the 1990’s of English police and probation officers (Crawford 1997), 84\% of police - but only 10\% of probation officials - felt that "too lenient sentences" had a considerable impact on crime, while $45 \%$ of probation officials - but only $10 \%$ of police - felt poverty did. ${ }^{5}$

In response to these kinds of issues, probably no other collaboration management technique is more widely discussed than trust building. A review (Mattesich and Monsey 1992) examining 18 studies on success factors for collaborations found that creating “mutual respect, understanding, and trust” appeared more often than any other (see also

\footnotetext{
${ }^{5}$ Likewise, $71 \%$ of probation officers (compared to $2 \%$ of police) listed anti-discrimination policies as one of the five most-effective crime prevention methods, and $41 \%$ listed employment/job-creation schemes (compared to 3\%); $44 \%$ of probation officers (and $83 \%$ of police) listed more police on the beat, and $12 \%$ (versus 33\%) surveillance cameras. A similar problem occurs when social service organizations representing different professions try to coordinate services: "Different professions develop different perspectives about the main problems affecting the multiple-problem client.” (Aiken et al 1975: 19)
} 
Crislip and Larson 1994; Smith, Carroll, and Ashford 1995; Bardach 1998; Linden 2002;

Shortell et al 2002; Huxham and Vangen 2005; Thomson, Perry, and Miller 2008).

b. Sharing power and workload equitably: To build trust, some (Huxham and Vangen 2005; see also Bryson and Crosby 2008) argue that fair treatment of partners, particularly less-powerful ones, is essential. In a private-sector interorganizational collaboration context (e.g. Ring and Van de Ven 1992; Chung, Singh, and Lee 2000) have argued that collaboration is more likely to be successful among organizations with relatively equal power. In collaborations, “[M]anaging the inequality between principal and subsidiary members frequently becomes an issue.” (Huxham and Vangen 2005: 219) It is therefore important partnerships not be dominated by one group (Crislip and Larson 1994; Linden 2002) and that workload be shared fairly so worries about free riding not deepen. These suggestions connect to literature (Tyler 1990) about the role of procedural fairness in gaining acceptance of decisions.

(2) Visionary leadership

Although literature on managing hierarchies has increasingly discussed visionary (Kotter 1990; Pfeffer 1992) or “transformational” (Burns 1978) leadership, which leads by inspiration more than command, this kind of leadership plays a more-prominent role in literature on collaborations, where command is less available (Mattesich and Monsey 1992; Melaville and Blank 1993; Crislip and Larson 1994; Bardach 1998; Carley et al. 2000; Lasker, Weiss, and Miller 2001; Linden 2002; Crosby and Bryson 2005; Gray 2009). "Determining a specific, easily articulated mission that reflects the interests of both individual organizational members and the large community partnership is an important characteristic of effective [collaboration] governance.” (Mitchell and Shortell 
2000: 2) Alexander et al. (2001: 165) see "vision-based leadership" as one of two essential management tools for partnerships.

\section{(3) Encouraging collaborative practices}

Almost by definition, the raison d'etre for collaboration is to accomplish things jointly that could not be done at all, or as well, by organizations acting alone. Encouraging such behaviors might thus become management priorities on their own right. They might also be adopted on the idea that attitude follows behavior rather than the other way (e.g. Freedman and Fraser 1966), so the best way to create attitudes conducive to collaboration is to encourage behaviors associated with it. Thought of in this second way, this should be seen as another collaborative management tool.

a. Information-sharing: A prominent example of a collaborative practice is information sharing (6 et al 2007). A major argument for collaboration is that it encourages sharing information found in several partners, that is useful to undertaking a task (Kelman 2006). In the context of collaboration across intelligence agencies, this is "connecting the dots"; for crime-reduction, it involves sharing knowledge about offenders that might exist, say, in police, youth offending, and probation organizations

b. Developing innovative local approaches: Nowell (2010: 95) writes:

A commonly represented vision of collaboration is the bringing together of multiple stakeholders who hold diverse perspectives on a problem thereby creating a forum for those perspectives to be identified, discussed, negotiated, and integrated. The result of this process is ideally a collection of stakeholders that have a more holistic perspective on a given issue. ...[This] is believed to serve as a foundation upon which new innovative solutions can be identified.

As Thatcher (2004) notes, views of collaborations that underplay their hierarchical elements often emphasize them instead as fora for dialogue and learning among partners. 
Here - as in team diversity literature emphasizing learning benefits of diversity (Horwitz and Horwitz 2007) - the suggestion is that the very range of cultures and approaches worrisome from a trust perspective produces synergy advantageous for learning. "By combining the individual perspectives, resources, and skills of the partners, the group creates something new and valuable together. ...Some people and organizations change when they are exposed to partners with different assumptions and methods of working.” (Lasker, Weiss, and Miller 2001: 184-85; see also Gray 1989; Bardach 1998; Rosenbaum 2002; Pollitt 2003). Making development of innovative local anti-crime initiatives, separate from those promoted centrally, a management priority would represent an effort to take advantage of these special features of a collaboration. (4) Followup and Delivery

a. Getting partners to follow though on commitments: Monitoring to check if people behave according to their commitments is a central feature of a manager's role in classic theories of hierarchy. Fayol (1949, originally published 1918) characterized two central management jobs as command and control -- reflecting a cycle beginning with a manager giving subordinates assignments and ending with checking that these have been accomplished. These morphed into two elements in Gulick and Urwick’s (1936) elaboration of "POSDCORB," under the monikers “directing” and "reporting."

Scholars emphasizing hierarchical elements of collaborations have noted this role as well. Though they emphasize mostly the benefits of centralization for reducing transaction costs of coordination inside a network, Milward and Provan also note (1995: 24) that "monitoring and control over activities and outcomes by the core agency become possible once a network is centralized.” Thatcher (2004; see also Shortell et al 2002) 
states that partnerships must, to be successful, "get [people] to follow through on their commitments"; Milward and Provan (2006: 18) write that collaboration managers "have a major responsibility to ensure that those who participate in a network are responsible for their share of network activities and are held accountable for their actions.”

b. Dealing with "blockages": Another common role discussed in literature on hierarchies is what Mintzberg $(1973: 82,85)$ calls "the manager as disturbance handler.”

When subordinates cannot agree among themselves, they seek the help of the manager; when no one knows how to handle a difficulty, they pass it about until the manager gets it; when a crisis is perceived, the manager must take immediate charge. ...[E]very manager must spend a good part of his time reacting very quickly to high-pressure disturbance situations.

Boulding (1964; see also Galbraith 1973) argues that one of the central roles of hierarchy is to establish a mechanism for dealing with disputes that cannot be resolved at lower levels, and whose resolution is required for the organization to act. This appears in POSDCORB as part of "coordinating."

We cannot locate any discussion in literature on collaboration management discussing this role. However, it came up frequently in the exploratory in-person interviews. The phrase generally used was dealing with "blockages” - crises, often involving conflicts among agencies, preventing some hoped-for activity from occurring.

c. Performance measurement: Starting in 2001 the U.K. central government established crime reduction targets. In 2005 these were assigned to CDRP's, not just to the police. Performance measurement appears as a control technique in the classical hierarchy literature: "The right to measure...results, and to specify what results are satisfactory...is the central component of managerial authority.” (Stinchcombe 1990: 58) 
More recently, use of performance measurement in individual public organizations has been widely discussed (e.g. Hatry 1999; Behn 2003; Moynihan, 2008).

Performance measurement has received the greatest attention of all hierarchicalstyle management tools in the collaboration literature (e.g. Shortell at al 2002; Linden 2002; Page 2003; Bingham, Sandfort, and O’Leary 2008). Bardach (1998: 148, 173) notes that "[t]he language of results will help the participants focus on the underlying rationale" for collaboration; he also argues they serve as "an instrument both of threat and of setting challenging goals...(that creates) 'a magnet for collaboration.’”

(5) Accessing Resources and Authority

a. Accessing central government funds: CDRP's have potential access to several sources of central government funds that require application (as well as base funding on a formula basis) Much of the early work on collaboration was written from a "resource dependence” perspective (Levine and White 1961; Benson 1975; Schermerhorn 1975; van de Ven 1976; Alter and Hage (1993; for crime partnerships, Liddle and Gelsthorpe 1994; Rosenbaum 2002), arguing this was the most-important reason organizations collaborated with each other in the first place.

When a collaboration seeks outside funds, it partly seeks to escape dilemmas of managing partner agencies by increasing resources the entity has available itself. Additionally, though, if collaboration entity itself can get access to resources individual agencies wouldn’t be able to obtain otherwise, this may build the collaboration's authority over partners, creating a more hierarchical-type relationship. In the pithy phrase of one proponent of human services collaboration (quoted in Bardach 1998: 191; see also Gans and Horton 1975), “Nothing coordinates like cash.” In a British context, it has been 
suggested that "[p]artnership working in practice consists of the temporary suppression of mutual loathing in the interests of mutual greed.” (Rowe and Devanny 2003: 375) The Mattesich and Monsey (1992) literature review found access to "sufficient funds" was one of the more-important factors explaining success.

b. Pressing partners to contribute more staff effort: An alternative way for a collaboration to gain resources is to implore partners to contribute them (often staff) to partnership activities. This tool does not seem to have been discussed in the literature, but was mentioned in our in-person interviews. Gaining staff resources would provide a partnership with people over whom it exercised some authority.

c. Gaining local chief executive support: The "chief executive" of a local authority is the senior career executive, analogous to a U.S. city manager. The chief executive has hierarchical authority over many agencies in a CDRP, though, importantly, not the police. Carley et al. (2000: 12) argue the chief executive, along with elected officials, are key in "drawing in reluctant partners" and encouraging their "genuine financial and human resource commitment.” They also argue such involvement "bring(s) visibility to the partnership" and "provid(es) evidence of commitment at a senior level."

d. Resolving issues of allocating government funds: Outside funds can also be a source of conflict (Lowndes and Skelcher 1998). We hypothesize that prioritizing managing such conflicts takes away attention from more value-creating activities.

(6) Engaging the External Environment

In collaboration literature, the Mattessich and Monsey review (1992; see also Crislip and Larson 1994; Milward and Provan 2006) found three studies (the minimum required for inclusion) concluding that a "favorable" political climate, where "political 
leaders, opinion-makers, persons who control resources, and the general public" support the collaboration's mission, promoted success. In one case study of a service delivery collaboration, Keast and Brown (2002) report the project foundered when it lost seniorlevel political support. In terms of crime reduction specifically, political support might help by increasing community engagement in crime reduction.

a. Gaining support from elected officials: A central argument in Moore (1995) is that gaining support from elected officials is crucial for a public manager’s success, since the external environment provides legitimacy. This may be especially important in a partnership as a way of establishing quasi-hierarchical authority, and thus may also be seen as a hierarchy-light tool. However, McGuire and Sylvia (2009) found that countylevel emergency collaboration managers who reported to an elected official were somewhat less likely to perceive the collaboration as successful than those who didn't.

b. Gaining good media coverage: Practitioner accounts (e.g. Linsky 1986; Haass 1994) emphasize the importance of working with the media for government leader success. Interestingly, this is not discussed in literature on partnerships. For crime, good coverage may help by engaging the community and/or persuading potential criminals the authorities are effective at catching perpetrators or that social tolerance for crime is low. One might, however, argue attention to media is negatively related to crime reduction, on the view (Payne 1980, regarding elected officials) that managers prioritizing media are "show horses" rather than "work horses," concerned about appearance over achievement.

b. Gaining voluntary sector support: Especially the British literature on partnerships pays significant attention to voluntary-sector involvement. Carley at al. (2000; see also Barr and Huxham 1996; Lee 1998; Gibbs 2001), discussing “urban 
regeneration” partnerships, argue voluntary sector involvement is important but difficult to achieve. In a police context, “community policing” (Skogan and Hartnett 1997) has emphasized the importance both of cross-organizational collaboration inside government and also involvement of local groups in crimefighting. By contrast, Rosenbaum (2002), in a crime-reduction context, expresses skepticism about the value of community involvement, arguing such involvement may make partnerships too large and unwieldy, and hinder discussion of confidential information about offenders.

\section{DATA AND METHODS}

\section{Dependent Variable}

For the period covered by this research, the U.K. central government established performance targets for crime reduction. For 2001-04 these were to reduce vehicle crime by $30 \%$ and domestic burglary by $25 \%$; there was an additional target to reduce robbery in ten "street crime initiative” areas (large cities) by 14\% (Home Office 2003). For 200508 , the target was a $15 \%$ reduction in the total number of crimes in nine categories of well-reported crimes - to vehicle crime, burglary, and robbery were added assault, wounding, vehicle interference and tampering, bicycle theft, theft from the person, and criminal damage (vandalism) (Home Office 2004).

Our dependent variable is the $2008-09^{6}$ crime rate by CDRP, aggregated for the nine crime categories of the 2005-08 target period, with lagged crime (2002-03) as one variable on the right-hand side. Crime data were provided by the Home Office from their

\footnotetext{
${ }^{6}$ Through July 1.
} 
internal data system, and we used population data to calculate rates. We logarithmically transformed crime so we can interpret coefficients as percentage impacts. ${ }^{7}$

Since CDRP's were formed in 1999, we would have liked to use crime data from that year, or earlier, as the baseline. However, crime data at the CDRP level only began to be collected in fiscal year 2001-02. Furthermore, in 2002 a new reporting standard was developed that increased reported crime in $2002-03$ by $10 \%$ compared with the previous methodology (Simmons, Legg, and Hosking 2003a). More importantly (since a uniform increase in crime across all CDRP's would not affect our results), the impact of the new standard varied by CDRP (Simmons, Legg, and Hosking 2003b), based both on when the new standard was implemented and on how much of a change it implied in previous practice. Additionally, in some jurisdictions, transition to reporting under the new system was not complete by the end of 2003. There is therefore a tradeoff between using an earlier year as baseline, so as to maximize our ability to observe CDRP treatment effects, and using a later year, to improve data comparability between baseline and final years.

Given this, we ran models using 2001-02, 2002-03, and 2003-04 as baselines. Substantive results (coefficients and p-values) were quite similar, but R2 was noticeably larger for 2002-03, and we therefore use this as our baseline for lagged crime.

It is unlikely that CDRP's, which were just getting established, would have produced effects on crime in their first three years. To the extent some CDRP effects may have already occurred by 2003, these will not be captured in our analysis, which makes any results conservative. And to the extent implementation of new reporting standards

\footnotetext{
7 To make results more intuitive, we reverse-coded crime, so a lower value (including a negative value if crime increased) means crime was higher. During this period, crime decreased in $69 \%$ of CDRP's in our dataset; changes ranged from a decrease of $51 \%$ to an increase of 55\%.
} 
was not complete in 2002-03, this introduces noise into our data and depresses p-values and coefficients, again making results conservative. Finally, six of nine categories used for our dependent variable were not objects of targets until 2005, halfway through our measurement period. To the extent this meant CDRP’s initially paid less attention to reducing crime in these categories, again this makes results conservative.

\section{Independent Variables}

Data for our independent variables come from a survey conducted between MaySeptember 2008 of community safety managers (the title of the person running the CDRP network administrative organization) in England and Wales. It was thus conducted towards the end of our measurement period, raising the question - to which we return later - about the extent to which reported priorities applied throughout the period, and whether this creates problems for our results.

The survey was conducted through, and with endorsement of, the National Community Safety Network, the association of these managers. It was initiated by an email explaining the purpose of the research and inviting the recipient to link to an online survey. Of the 372 CDRP's, emails were sent to 339 managers. ${ }^{8}$ If the manager reported being in post less than one year, we aborted the survey, requesting the recipient provide contact information for the predecessor. Four reminders were sent, after which efforts were made to interview by telephone. ${ }^{9}$ This produced 203 completed surveys (102 online and 101 by telephone ${ }^{10}$ ). Excluding 26 managers not in post long enough and unable to help locate their predecessor, the response rate was 65\%.

\footnotetext{
${ }^{8}$ For the rest, either no address could be obtained, or they bounced back because of a incorrect addresses.

9 The telephone survey was conducted in January-February 2009.

10 Phone interviews were not completed for the following reasons: (1) 82 no answer or no reply to voicemail after 6 attempts; (2) 27 refused (6) 21 requested Internet survey link but then didn't respond.
} 
The survey had a large number of questions; data for our independent variables come from one of them, in which the manager was presented a list of 15 management practices. (Exact question wordings appear in Table One.) The list was introduced with the following statement: "The following is a list of possible management priorities for a Community Safety Manager. For each of the factors listed, please tick the box that best describes how important each priority has been for you personally as a Community Safety Manager.” (emphasis in original) The choices were: (1) "This is a top priority,” (2) “This is important to me,” (3) “I pay some attention to this, but it’s not a real priority," and (4) "This is not something I pay much attention to." If the respondent gave more than two practices the top rating, an instruction appeared on the screen to limit the number of top priorities to two. ("Which of the following have been the highest priorities for you? Please choose either one or two areas.”) We did this to make sure we got variance, rather than allowing respondents to say they prioritized everything.

This procedure generated self-reported values ranging from “1” to " 5 ," where " 1 "=the highest priority, either as stated initially or after the respondent was limited to two top priorities, “2”=second-highest priority as stated on the survey or initially presented as highest priority, but not among the top two chosen after the followup, and each other value moved down one notch (e.g. original " 3 " became "4") to reflect this recoding. To make interpretation more intuitive, all values have been reverse-coded.

These answers do not allow us to take into account variation in how managers used a technique - managers may prioritize performance measurement, or trust building, in different ways. This is similar to a problem in evaluation research - using exposure to a broadly defined "treatment" such as participation in Head Start to examine its 
relationship with an outcome masks enormous differences in the content of Head Start programs (Light, Singer, and Willett 1990). However, this introduces noise, and thus depresses coefficients and p-values. Similarly, we cannot distinguish whether a technique was used well, and skillful use presumably relates more to success. Finally, the decision to prioritize a practice may have been influenced by perceived poor performance in the area; since what we care about is the influence of doing a better job with the management activity prioritized; if choices occurred to compensate for baseline bad performance, this would bias coefficients for the practice downward.

Due to the way the Internet survey was set up, it was difficult to avoid answering a question, so we had few (between one and three) missing values. Values for these few were imputed so as not to lose an entire observation because of one missing value. ${ }^{11}$

\section{Control Variables}

Factors at the local authority level other than a CDRP's management practices may be related to crime performance. These include: (1) demographic characteristics ${ }^{12}$; (2) general organizational capacity of the local government, which might make it easier for any local government organization, such as a CDRP, to succeed at anything it attempts, separate from specific practices of CDRP managers; (3) a greater level of social trust among people, which makes collaboration across organizations easier. ${ }^{13}$

\section{Demographic variables}

\footnotetext{
${ }^{11}$ Though there were few non-responses, they were generally for different questions, so we would have lost about 25 respondents with no imputation. Imputation was performed using the other management practice variables as predictors.

12 Some demographic variables such as poverty are generally believed to be associated with levels of crime, but there is less reason to expect that demographic levels will be associated with crime levels controlling for past crime levels - as we do in our model - and thus in effect for changes in crime. ${ }^{13}$ For some of these control variables, we had missing values, occasionally as high as for $10 \%$ of the observations. In these cases we imputed missing values, using the other control variables as predictors.
} 
We measured (1) population (log); (2) scores on a government-compiled Index of $\underline{\text { Relative Deprivation }}^{14}$; (3) unemployment rate; (4) percentage of male teenagers in the population. For most variables, data came from the 2001 census at the local authority level (coterminous with CDRP boundaries). Local Government General Organizational Capacity

(1) Comprehensive Performance Assessment score: In 2002 (2003 for district councils) the Audit Commission, a national body, first produced annual overall performance ratings for local authorities (Audit Commission 2005). We use the overall score for the first year these were available. Scores range from “1” (“poor”) to “4” (“excellent”).

(2) overall public satisfaction with local government: We use data from a 2000 survey of residents in each local authority, ${ }^{15}$ and use the percentage "very" or "fairly" satisfied. (3) public satisfaction with local street cleanliness: We use data from the same survey. (4) unitary authorities and district councils: England has a mixed system of local government. There are both "unitary" local authorities and "two-tier” ones (Wilson and Game 2006). Two-tier authorities, in sparsely populated areas, divide up local responsibilities into higher-tier county and lower-tier district councils. This is often regarded as making collaboration in a CDRP more difficult, because the CDRP exists at the lower level, but some partner organizations are at the upper one. An observation is coded “ 1 ” if the authority is unitary, zero if part of a two-tier council.

(5) political stability: Democratic theory would suggest that greater partisan competition, which would produce lower party-political stability in the control of local government, would improve government performance by increasing rewards to performance. On the

14 This has frequently been used as a control variable in empirical research (e.g. Andrews et al 2005) on public management in the U.K.

${ }^{15}$ Accessed at http://www.neighbourhood.statistics.gov.uk/dissemination/ 
other hand, partisan stability may create incentives for longer-term capacity-building efforts, such as creation of collaborative capacity, that don't yield immediate results (O’Toole and Meier 2003). We measure political stability by first looking at for how many years between 2000-08 each party (Labour, Conservative, Liberal Democrats, or another party) controlled the local council. ${ }^{16}$ Our measure is the number of years the party with the longest period in power held power (BBC News 2009). ${ }^{17}$

\section{Social Trust}

There is some empirical literature (e.g. Glaeser et al 2000; Putnam 2007) suggesting that higher levels of diversity in a community are associated with lower social trust. This is consistent with literature on "outgroups" (Sherif et al 1961; Tajfel 1971; Brewer 1979), finding that people readily differentiate in- from out-groups, and that ingroup cooperation with outgroups is often difficult. There is also evidence (Putnam and Campbell 2010) frequent church attenders tend to be more trusting than others. ${ }^{18}$ As proxies, we therefore measured (1) percentage Christian; (2) percentage Muslim; (3) percentage white; (4) percentage foreign born; (5) percentage attending church (Brierly 2007); and (6) percentage minority employees in the local authority government (Audit Commission 2003). Data for the first four measures come from the 2001 census.

Effort

In addition to control variables involving extra-CDRP influences, we also tested measures of overall CDRP level of effort. Our independent variables measure relative,

\footnotetext{
${ }^{16}$ So if Labour was in control for 5 years, the Conservatives 2, and the Liberal Democrats l, the values would be Labour=5, Conservatives=2, Liberal Democrats=1. If no party had control for a given year, that year was not counted towards any party's number of years.

${ }^{17} \mathrm{So}$ in above example, the value of the variable would have been 5 . If there was a tie - e.g. Labour 4 years, Conservatives 4 years, the value of the variable was the tie value (here, 4 ).

${ }_{18}$ This finding is confounded in U.S. data by the fact that Protestant fundamentalists tend to be high attenders and low trusters.
} 
not absolute, effort. Say that in one CDRP, the relative priority of practices A and B is 5 (highest) and 1 (lowest), while in another it is 1 and 5. However, it is possible that overall effort in the first CDRP is so much higher than the second that actually more B was done in the first CDRP. Including effort allows us to compare the impact of prioritizing a practice, controlling for overall CDRP effort levels. We therefore tested for the impact of effort both as a main effect in the model and interacting with our treatment variables. ${ }^{19}$

\section{Analytic Approach}

\section{Testing for Interactions}

It is plausible to believe that some management practices might be more effective in some background circumstances. For example, input-output thinking would suggest that presence of greater underlying social trust might allow for more-efficient transformation of a given level of a management inputs into crime-reduction outputs; in CDRP's with higher levels of social trust, a given investment in promoting information sharing, say, might produce greater crime reduction. However, one might imagine the opposite, namely that underlying trust and investments to build trust are substitutes. In this view, if there is high initial trust, prioritizing trust creation is less necessary, and might have a lower impact on crime than in places with low initial trust, where this priority might make a bigger difference. One might also theorize some practices might work better in areas with larger population - for example, larger jurisdictions might do a better job transforming investments in performance measurement into crime reduction --

\footnotetext{
19 We measured effort in several ways. A question in the survey asked respondents to rate, on a 1-10 scale, "the level of commitment" of several organizations "to partnership working in or with your CDRP." The organizations listed were the police, fire service, probation service, health service, schools, city services, youth offending services, and the voluntary sector. We measured effort as commitment level of police only, probation only, and youth offending service only; also as a mean score for all three of these organizations and for all eight together.
} 
because greater size makes it easier to pay fixed costs of hiring staff to run these systems. Other examples might be that greater partisan stability might increase effectiveness of efforts to cultivate politicians, since one is more likely to be dealing with similar leaders over time. All these relationships would be hypothesized to create interaction effects.

It is, however, difficult to have good a priori hypotheses - and there is no literature on this -- for the many effects one might speculate could be significant, for theorizing has been low and empirical testing even lower. This argues, in research such as this presenting some of the first empirical tests of the influence of management practices on collaborative success, for casting a wide net and testing many possible interactions.

On the other hand, researchers are often warned against “data mining” - doing a large number of tests on a dataset with no theoretical justification. A large number of tests creates the probability that, just by chance, at least some relationships will be significant. Also, with our relatively small sample size, putting all potential interactions into one equation would be a recipe for insignificant p-values and multicollinearity.

In light of these tradeoffs, the following strategy was adopted: (1) For all background variables possibly interacting with management priorities to explain crime, one-by-one interactions were run (including significant control variables); (2) We further examined interactions when the treatment interacted at the .1 level with at least two background variables, to guard against chance effects; ${ }^{20}$ (3) We entered interactions thus produced in a stepwise regression (Efroymsom 1960) to eliminate insignificant ones. ${ }^{21}$

\section{Endogeneity Issues}

\footnotetext{
${ }^{20}$ Since a number of the control variables examined -- percentages foreign born, Christian, Muslim, and white -- were highly correlated, we chose for further examination the one (percentage foreign born) with the largest number, by some margin, of significant one-by-one interactions.

${ }^{21}$ We tested both backward and forward elimination methods using STATA 9.2. Both produced similar results, but the R2 for backward elimination was higher, so we used this technique.
} 
One of the issues in our ability to make inferences from current priorities is whether choice of priorities is endogenous -- rather than priorities causing changes in crime over time, changes in crime cause changes in priorities. ${ }^{22}$ Although our dependent variable is current crime, values for this variable are influenced by changes in crime over time, creating potential endogeneity problems.

We were most concerned about this possibility for prioritizing relations with the media. If crime goes down, managers may prioritize media relations more, because they have a better story to disseminate. Less plausibly, prioritizing relations with politicians might be similarly influenced. ${ }^{23}$ Any positive coefficient for the impact of prioritizing media relations, or perhaps those with politicians, might thus reflect endogeneity.

The standard method for dealing with potential endogeneity is two-stage least squares regression (Greene 2007), using instrumental variables. We tested several measures of newspaper penetration at the local authority level as instruments, on the view higher penetration of local media would exogoneously be associated with greater prioritization of media relations, since the more-important the media, the more attractive it becomes to seek to influence coverage. ${ }^{24}$ However, none proved to be acceptable instruments; all had F-statistics smaller than 10 in a first-stage regression. So we were forced to retain OLS. However, differences in mean prioritization of both media and elected official relations between those who had changed priorities because they feared

\footnotetext{
${ }^{22}$ Although our dependent variable is current crime and not change in crime, current crime is partly dependent in change in time over crime, so the potential endogeneity problem remains.

${ }^{23}$ If crime goes up, community safety managers might well be inclined to seek "cover" by prioritizing relations with politicians - but politicians would likely resist, making prioritization efforts self-limiting. If crime goes down, politicians might seek to associate themselves with the CDRP, but this wouldn't imply that the priority of relations with politicians for the community safety manager would increase.

${ }^{24}$ The measures of local media penetration we tested as instruments were (1)the total number of local newspapers in the local authority, (2) the total circulation of the local newspapers, (2) the household penetration of the highest-circulation local paper. Our data came from Newspaper Society (2010).
} 
not meeting targets and others (see below) was small - for media, almost non-existent and statistically insignificant, arguing against endogeneity.

There is a second way changes in crime might affect priorities. If performance is seen as unsatisfactory, managers might look to change priorities because previous ones weren't working. Such behavior would correspond to the theory of problemistic search (Cyert and March 1963), which argues organizations continue existing practices unless faced with problems, at which point they search for new ones. Such changes, however, might well generate random reshuffling, but not create net movement on any of them. (If managers knew which practices worked, presumably they would have used them before performance deteriorated.) If bad crime performance simply randomly changes priorities, coefficients do not become biased. ${ }^{25}$ However, for a number of the practices, one might make a priori arguments why managers might non-randomly change the priority if performance worsens. For example, managers might make building trust or encouraging information sharing higher priorities, because these have been so widely proposed as essential to partnership success and are thus more available for choice (Bazerman and Moore 2009). To the extent shifts among priorities in response to performance problems are non-random, this also creates endogeneity problems. Unfortunately, for practices about which we asked, no good potential instruments are available.

Since we were aware of potential endogeneity when the survey was designed, we developed another technique to take account of it. In the survey, we asked respondents, “Have your priorities changed over the last year?” We gave a number of alternatives, of which one was: "Yes, because we were concerned we will not meet our PSA [Public Service Agreement] targets.” 26 respondents checked this response. We then compared

\footnotetext{
${ }^{25}$ This would create noise, making any results conservative.
} 
their mean values for prioritizing the different practices with those of other respondents. We found difference were statistically significant (at .1) for only one treatments (trust creation), a result no better than chance given we have 15 treatments, suggesting random redistribution of priorities. ${ }^{26}$ We therefore present our results using all respondents. Testing for Interactions

It is plausible to believe that some management practices might be more effective in some background circumstances. For example, simple input-output thinking would suggest that presence of greater underlying social trust in a community might allow for more-efficient transformation of a given level of a management inputs into crimereduction outputs; in CDRP's with higher levels of underlying trust, a given investment in promoting information sharing or reducing blockages might produce greater crime reduction. However, one might also imagine the_opposite, that underlying trust and conscious investments to build trust serve as substitutes. In this view, if there is high initial trust, prioritizing trust creation for conscious effort is less necessary, and might have a lower impact on crime than in places with low initial trust, where this priority might make a bigger difference changing trust across organizations. One might also theorize a number of practices might work better in areas with larger population, because greater organizational capacity, made possible by larger population, might also make for more-efficient transformation of inputs into outputs. Larger jurisdictions might do a better job transforming investments in performance measurement into crime reduction, because greater size makes it easier to pay fixed costs of hiring staff to run these systems. Other examples might be that greater partisan stability might increase the effectiveness of

\footnotetext{
${ }^{26}$ Even for trust, poorer crime performance was actually associated with lower prioritization, the opposite of our endogeneity worry, but creating the risk that coefficients might be inflated.
} 
efforts to cultivate politicians, since one is more likely to be dealing with similar leaders over time. All these relationships would be hypothesized to create interaction effects.

It is, however, difficult to have good a priori hypotheses for the many effects one might speculate could be significant, for theorizing has been low and empirical testing even lower. This argues, in research such as this that presents some of the first empirical tests of the influence of management practices on collaborative success, for casting a wide net and testing many possible interactions.

On the other hand, researchers are often warned against "data mining" - doing a large number of tests on a dataset with no theoretical justification. A large number of tests creates the probability that, just by chance, at least some relationships will be significant. Also, with our relatively small sample size, putting all potential interactions into one equation would be a recipe for insignificant p-values and multicollinearity.

To deal with these tradeoffs, the following strategy was adopted: (1) For all background variables believed on theoretical grounds to have possible interactions with management priorities in explaining crime reduction, one-by-one interaction regressions were run for each background variable with each treatment (along with the significant control variables); (2) We only further examined interactions when the treatment significantly interacted at the .1 level with at least two background variables, to guard against chance effects; ${ }^{27}$ (3) We entered all significant interactions thus produced into our model. (4) We eliminated non-significant interactions one by one, until only significant ones remained; we retained these, subject to there being a plausible account, even if $\underline{\text { ex}}$ post, of why the effect was occurring.

${ }^{27}$ Since a number of the control variables examined -- percentage foreign born, Christian, Muslim, and white, were highly correlated, we chose for further examination the one (percentage foreign born) with the largest number, by some margin, of significant one-by-one interactions. 


\section{Other Data Analysis Issues}

We analyzed our data for non-response bias, comparing respondents and nonrespondents on our control variables. ${ }^{28}$ We found non-respondents were from local authorities with significantly (.05 level) lower comprehensive performance assessment scores and higher political stability, and were less-likely to be from London, Wales, or lower-tier authorities, though differences in means were small. To correct for this, we performed weighting adjustments. We first ran a logistic regression with a dummy indicating either respondent/non-respondent as y, and characteristics differing between the groups as x’s. From the regression, we took the predicted probability of response for each observation and adjusted the regression by weighting each observation with the inverse of this predicted probability (Dey 1997). ${ }^{29}$

We used OLS to analyze the data. We first ran the model with controls only, retaining only significant ones. We centered all but binary variables (London and Wales) around their mean values to reduce multicollinearity (Aiken and West 1991); no VIF score was greater than 3.7. We use robust standard errors clustered by police force. $^{30}$

\section{RESULTS}

Table 2 presents means and standard deviations for management priorities and other variables. Table 3 presents regression results. R2 is .70. Of control variables, only initial crime, population, and church attendance were significant as main effects. Thus, no

${ }^{28}$ We were able to do this because we had values for these variables for all CDRP's.

29 There were no differences between respondents to the Internet and telephone surveys.

30 Police districts for each CDRP are grouped into 42 contiguous forces, which have some common command structure. Clustering accounts for observations within each force not being independent but correlated in unknown ways. Robust standard errors adjust for possible heteroskedasticity in the error term. 
organization capacity variable, and only one demographic and social trust variable each, explained crime controlling for initial crime. Initial crime explained $48 \%$ of variance, while the other two control variables added a further 3\%. Adding treatments and interactions explained a (quite large) additional 18\% of the variance.

\section{Hypothesis Testing}

We find there are management practices associated with more success at reducing crime, mostly exhibited through interaction effects such that a practice is effective in some circumstances but not others. There are also some practices that can make performance worse (there is a negative coefficient for the treatment); given that respondents were asked to prioritize practices compared with each other, this suggests the opportunity cost of choosing those and therefore spending less time on others, given management capacity is limited, is greater than benefits from the activity. (An alternative possibility is that a priority may have been selected because performance in that area was seen as poor, which would, as noted earlier, would depress coefficients downward.)

Table 4 presents interpretations of our interaction results - coefficients for a oneunit change in the treatment at the mean value for the background variable, and at one standard deviation below and above that variable's mean. Given that our dependent variable was log transformed, coefficients may be interpreted as percentage declines in crime associated with a one-unit treatment change (on a 1-5 scale). Table 5 indicates the percentage of CDRP's, and the percentage of the total population living in those CDRP's, where the sign of the treatment coefficient is positive. To simplify our presentation, when we say "crime decreases by $x \%$," we mean a one-unit change in the treatment is 
associated with a reduction of crime by that percentage; given the size of the standard deviation for treatments, such a change is somewhat more than one standard deviation.

The most-dramatic finding is that the practices most consistently relating to better performance are ones associated with what we have called "hierarchy light.” Prioritizing five of six such techniques predicts better results, at least in some circumstances. The strongest effect was for getting partners to deliver on commitments, which had the strongest impact on crime (a 2.6\% reduction) for the average CDRP, and tied for the highest impact ${ }^{31}$ (4.8\% decline) where used under conditions making it particularly effective. (This is in local authorities with a higher proportion of male teens, where cooperation among agencies is particularly crucial.) The second-strongest effect was prioritizing removing “blockages.” It is associated, in local authorities with better overall performance (high Comprehensive Performance Assessment scores), with a 3.8\% crime reduction. In high CPA areas, individual organizations are effective, so working to unblock problems among them can make a difference. However, as for other variables to be discussed here, if used in unfavorable circumstances (low CPA), prioritizing this practice has a negative impact on crime.

Prioritizing performance measurement reduces crime if used in favorable circumstances - CDRP's with larger populations and high CPA scores. For CDRP's (outside London) with log population one standard deviation above the mean, crime goes down by 2.8\%. For CDRP's in local authorities (outside London) with high CPA scores, it is associated with $1.9 \%$ decrease; well-performing organizations can better respond to needs for improvement that performance measurement suggests. ${ }^{32}$ In CDRP's at mean

${ }^{31}$ Except for some of the impacts of London and Wales.

32 In London CDRP's, prioritizing performance measurement hurt crime performance. 
population and CPA scores, prioritizing measurement has no effect. Prioritizing bidding for government funds reduces crime $3.6 \%$ in politically more stable local authorities. A more politically stable environment may make it easier to translate a CDRP's access to funds to greater hierarchical-style influence. ${ }^{33}$

Outside London and Wales, prioritizing obtaining chief executive support reduces crime in areas with a larger population. In CDRP's outside London and Wales, it is associated with a 3\% decrease in crime; larger governments are more difficult to coordinate, especially the many city services organizations, and chief executive support can help avert entropy. ${ }^{34}$ (We discuss below the positive impact of engaging elected officials, which may also increase the CDRP's quasi-hierarchical authority.)

By contrast, prioritizing only two of five techniques used specifically for managing collaborations reduces crime, and some have a negative impact. As the literature predicts, prioritizing trust creation has a strong effect, especially in CDRP's with lots of teens. On average, prioritizing trust creation reduces crime by $1.2 \%$; in CDRP's with a high percentage of teenagers, crime went down by $4.7 \%$ (in those with few teenagers, crime got worse), the second highest effect size we saw. Fighting youth crime requires collaboration among agencies with different cultures, and investments in

\footnotetext{
33 It might hypothetically also make it easier to obtain funds, heightening results of the prioritization. As predicted, prioritizing dealing with conflicts over dividing up government money hurt performance (except in London), especially in CDRP's with many male teens.

${ }^{34}$ Prioritizing chief executive support also reduces crime in areas with fewer male teens and hurts in those with many teens. Collaboration regarding at-risk teens crucially involves two organizations, police and probation, not part of local government and thus not under chief executive influence; so in these places, prioritizing chief executive support seems to create opportunity costs.
} 
trust building help..$^{35}$ Another "encouraging collaboration" practice, developing local initiatives, has a small positive effect (1\% crime decrease), except in Wales.

Prioritizing no other collaboration-style practice reduces crime, except for some in London and Wales. Prioritizing the other technique for promoting voluntary cooperation, working to share power equitably, is associated with poorer performance (1.6\% crime increase), except in London and Wales. ${ }^{36}$ The other "promoting collaboration” practice, information sharing, has a very slightly negative effect everywhere but Wales, where it has a large negative effect. This is particularly noteworthy given the high importance promotion of information sharing has been given as a collaboration management tool. Prioritizing communicating a vision has a negative effect (2.2\% crime increase), except in London, where the impact is positive. These results presumably reflect the opportunity costs of prioritizing practices that don't help.

Positive effects in London of working for equitable treatment of partners, of communicating a vision, and even of managing conflicts over distribution of funds along with the negative impact of prioritizing chief executive support ${ }^{37}$ - suggest that overcoming challenges of managing in a big city's fractious environment require more collaboration-management style approaches; in Wales, the positive impact of working for

${ }^{35}$ Given trust creation was prioritized more highly where crime went down, creating a risk of inflated coefficients, we examined the impact of trust among the 177 respondents with unchanged priorities, and found it to be similar.

${ }^{36}$ Some coefficients for interactions between London/Wales and priorities seem large, suggesting implausibly large impacts on crime. For London, standard deviations of responses for the mostsuspiciously large-coefficient treatments (chief executive, equitable power distribution, and visioning) are noticeably smaller than for the non-London sample -- .59 vs. .87, 64 vs. .86, and .68 vs. . 80 -- so a change in crime at one standard deviation becomes more reasonable with actual London respondents. For Wales, standard deviations are similar to the sample as a whole. We also examined bivariate scatterplots of the treatment and change in crime, to see if one outlying observation was driving the relationship, given there were only 15 London and 18 Wales observations. Inspection did not show this to be important. With small subsample sizes, the likelihood that intra-London/Wales relationships are due to chance rises.

${ }^{37}$ Note that since London CDRP's are generally in above-average population areas, and since there is a positive relationship between population size and the impact of prioritizing performance measurement, the negative coefficient would be lower for most actual London CDRP's. 
equitable power sharing and the negative one of prioritizing chief executive support may link to a more egalitarian culture. In all, our results suggest collaboration-style techniques work better in London and Wales, perhaps for different reasons. One may speculate that large cities have been over-represented in research on cross-agency collaborations, perhaps producing a bias towards emphasizing special features of collaborations. ${ }^{38}$

Prioritizing two of the three practices for engaging the external environment had positive effects, at least under some conditions. Engaging politicians generally had a strong impact, especially in areas with high initial crime. On average, prioritizing relations with elected officials reduced crime by $2 \%$; where initial crime was high, the effect was 4.4\%., our third-highest effect size. Plausibly, this occurs for two distinct reasons. Where crime is high, politicians may become more actively involved in mobilizing the community against crime. Additionally, especially in high-crime areas, they may put more pressure on individual organizations to work together in the CDRP, increasing the CDRP's hierarchical authority. The role of elected officials in helping collaborations enhance such authority has not been noted in the literature.

Additionally, for CDRP's in well-performing local authorities, prioritizing media relations is associated with a $4.9 \%$ crime reduction, tied with prioritizing followup for the strongest effect size (for the average CDRP, this priority reduces crime by $1 \%$, considerably lower than the mean effect of followup; crime went up where local authorities were poorly performing). We discussed earlier how good media coverage might reduce crime, and it may be easier to obtain such coverage where government

\footnotetext{
38 We note another pattern for Wales. For three of four treatments where Wales is different, the coefficient is negative. This suggests greater competition for management capacity, such that mistaken choices are not merely useless but crowd out useful activities, suggesting a capacity deficit compared with England.
} 
performs well generally and hence reporters are more likely to believe positively spun stories. Together with the strong impact of prioritizing relations with politicians, the finding about media suggests the importance of community mobilization for success, though this impact will depend on a partnership’s substantive area of activity.

None of our effort measures was neither significant as a main effect, nor did they significantly interact with any management practices in explaining crime reduction. ${ }^{39}$ However, initial crime was very important in explaining change in crime - the correlation between these two is .68. The higher initial crime in a CDRP, the more crime went down This finding is qualitatively similar ${ }^{40}$ to that reported by Zimring (2007) for differences in reduction in homicides in big cities and rural areas in the U.S. in the 1990's. Some of this is surely due to regression to the mean, but high initial crime areas are generally those one would expect, not ones randomly becoming so in $2002 .{ }^{41}$ And crime reductions have not always followed this pattern - for example, in New York City in the 1990's, where there was a uniform citywide anti-crime strategy, crime went down by similar percentages in both low and high crime areas (Farrell personal communication, 11/19/2009). ${ }^{42}$ It is plausible to believe that in CDRP's, which unlike New York could develop varying approaches and commitment levels, overall effort increased where the initial problem was worst. By this measure, then, overall effort did likely affect CDRP success, an interesting finding with relevance for conclusions about the ability of

\footnotetext{
${ }^{39}$ Very few interactions were significant even done one-by-one. We also tested for significant triple interactions involving the significant interactions involving the treatments. For two of the specifications of effort, greater effort was associated with greater crime reduction if performance measurement was a priority in London, and for police effort, it was associated with greater success if information sharing was a priority in Wales. In neither case was the significance of other interactions affected.

40 Zimring's data (which divide jurisdictions only into two categories) do not permit calculation of a correlation like what we have for our data.

${ }^{41}$ Zimring looks at jurisdiction size, not initial crime, so regression to the mean isn't an issue.

${ }^{42}$ Between 1993 and 2008, crime in the highest-crime precinct declined by 69\% and in the lowest-crime precinct $80 \%$.
} 
government to make progress on a problem based on greater effort at addressing it. But our results for the management priorities already control for any overall effort impact of initial crime, since it appears as a main effect in our model, and there were no significant interactions between initial crime and the treatments.

It is unlikely our results come from mere data mining. We checked how many significant interactions were obtained in simulations when we imposed a data- generating process reflecting the features of our data but imposing zero coefficients on the interactions. The goal was to see whether we would obtain as many significant interactions through a data mining process as in our model. ${ }^{43}$ We ran the simulation 500 times. In our model, we found 20 significant interactions at the .1 level or better; for the simulation trials the average number was 8.2. Of the 500 trials, none had as many as 20 interactions that were significant at .1 . We also checked the number of interactions at other significance levels for 20 trials. $^{44}$ In our model, we found 11 interactions at .01 or better, for the trials 3.6; and 6 at .000 or better, for the trials 1.7.

\footnotetext{
43 To perform the simulation, we generated regression coefficients for the treatment and control variables from a model with main effects only. Then, using our real data for values for the treatments and controls, and these coefficients, we generated, for each observation, new values for $y$ that were predicted by the overall coefficients for this model. These values, by construction, exclude any effects of interactions. To create the simulations, we then sampled our observations 203 times with replacement (each time we chose an observation, we "returned" it to the sample, so it had a chance to be sampled again). We then used actual data from this new sample, along with values for $y$ we created, to test for interactions using the same stepwise method used in developing the model we present here, to see how many interactions were generated. Any interactions generated are pure products of chance, since the method precluded genuine interactions. We are grateful to Alberto Abadie for suggesting this method; it is similar to one used in Bertrand, Duflo, and Mullainathan (2004).

In a test with 20 trials where we examined the results manually, the simulated equations showed much higher multicollinearity than did our real model - for almost half the highest VIF score (with centered data) was over 10, ranging from 10.3 to 85.1, while for our real model, the highest was 3.7; this suggests interactions generated by the simulation are suspicious, unsurprising given these in fact were chance phenomena. Even where the highest VIF was under 10, the maximum ranged from 4.4 to 9.9, with a mean of 6.8, well higher than the maximum VIF in our actual model. Indeed, though most texts use a cutoff point of 10 for serious multicollinearity concerns, at least one text (Menard 1995: 66) states that a maximum VIF over 5 is a "cause for concern." Since we would not have used a real model with maximum VIF over 10, in the 500 trial simulation, we excluded through the programming instructions trials with such scores.

${ }^{44}$ These had to be checked by hand, so doing this 500 times would have been difficult.
} 


\section{DISCUSSION AND LIMITATIONS}

In finding there are certain practices followed by collaboration managers that are associated with greater success at achieving results, this study provides evidence for the broader proposition that interagency collaborations, properly managed, can improve public performance. Impacts on crime from the choice of more-effective practices are modest - a few percent - but investments in CDRP's are also relatively modest, so it is likely the benefits of a well-managed collaboration outweigh the costs.

Our study should be seen in the context of research on whether "management matters” (Lynn et al 2000; Meier and O’Toole 2002; Moynihan and Pandey 2005; Ingraham et al 2003) that hitherto has involved single organizations only. We believe this is the first study providing evidence "management matters" collaborations.

These findings also support arguments of those arguing effective management of collaborations is associated not with tools for managing collaborations specifically, but with those for managing any organization, along with techniques for engaging the external environment common for managing any government organization.

Similar to the finding of Kelman and Myers (2011) that public executives successful at executing ambitious goal changes differed from those who tried but failed not in using change management techniques but in using general management ones, our findings suggest that if you want to be a good collaboration manager, you should be a good manager, period. Furthermore, three treatments interacted with the local government's overall performance rating, such that techniques for managing a $\underline{\text { collaboration worked better in an environment where single agencies worked better. }}$ Aside from effects of London and Wales, this produced our largest number of 
interactions. The local rating did not lower crime as a main effect; good individual agencies do not by themselves produce successful collaborations. But the interactions suggest that well-performing agencies create an environment where good management of a collaboration has more impact. This suggests that if you want collaborations among agencies to succeed, you need to worry about the health of the individual components.

The hierarchical tools that work for collaborations are back-end ones, along with ones for gathering external resources and support, rather than front-end tools unavailable to them. However, without such "hierarchy light" tools, collaborations might fall victim to entropic and disintegrative forces that would reduce partner effort over time. The distinction between unavailable front-end tools -- such as hiring, task assignment, and work direction -- and those hierarchical tools that are available to collaborations has not heretofore been noted in the collaboration literature.

The impact of engaging the external environment on improved performance plausibly at least partly due to the community involvement in achieving the collaboration's goals such engagement engenders -- is a second finding with implications for collaboration management. The ability to engage the community may be more available to interagency collaborations than to individual organizations, due to the greater legitimacy coming from the multiple constituencies different agencies represent. Here, it may be easier for a CDRP to engage the community than for the police to do so by themselves. Depending on the specifics of a collaboration's agenda and the agencies composing it, this may provide an opportunity to which collaborations should attend. Our findings has prescriptive implications for managers. In an interesting study comparing the managerial behaviors of local emergency managers leading their own 
organizations with their behavior leading local emergency manager networks, Silvia and McGuire (2010) found that these managers made relatively far greater use of collaboration-specific techniques in managing collaborations and hierarchicalmanagement techniques in managing their own organizations. Our findings suggest that managerial priorities may need to be rebalanced. ${ }^{45}$ Furthermore, the many interactions we found allow us to offer advice: for example, though there is often a positive relationship between prioritizing performance measures and better results, managers in lowpopulation, or poorly performing, local authorities should not choose this priority.

Like all research, ours has limitations. Since our study is empirically located in a specific environment, we cannot be sure about its external validity -- our ability to use these results to give advice to other managers that selecting these priorities will improve the success of their collaboration. These results apply to a collaboration mostly inside government, where the police are a crucial partner. Hierarchy-like management techniques may be more effective in this than in other collaboration environments, also possibly limiting the external validity of these results. ${ }^{46}$

An important potential limitation is that we only have data on current priorities, which may not be consistent with those of the past, creating measurement error. Ideally, we would like a measure of priorities for each year during the treatment period and then construct some sort of average measure. The near-impossibility of locating CDRP managers for the whole period made this approach infeasible; even had we such data, one could imagine many specifications for the best averaging method, none clearly correct.

\footnotetext{
${ }^{45}$ The mean prioritization values for our CDRP managers in Table 2 (with no comparison to their behavior in other contexts) did show significant attention on average to these practices.

${ }^{46}$ We are grateful to Michael McGuire for suggesting this point.
} 
There is evidence suggesting some persistence in priorities over time. We have surveys for a limited number (30) of a CDRP's first community safety manager. Where we also had data for the corresponding current manager (22), we regressed for each practice the prioritization of the first manager on that of the current one, to see whether stability existed over time. Correlations were all positive, ${ }^{47}$ and generally around .25 , though, with our small sample size, only two were significant at .05 (performance measurement and bidding for funds) and another at .1 (information sharing). We also noted the number of observations for which one or two of the highest priorities for managers during the two periods were the same, and compared this with the chance occurrence of the same priorities: the probability based on chance that the two managers shared at least one priority was $25.7 \%$, while the actual probability was $40 \%$; $10 \%$ of managers shared the same two top priorities (compared to a probability based on chance of less than 1\%). ${ }^{48}$ Furthermore, for all 30 observations we calculated a rank-order correlation of the means of the 15 treatments over time; the Spearman rho is a very high $.65(p=.008)$, suggesting there are certain priorities that, in general, are seen as more important (the way almost everybody would prioritize a lifetime of happiness over a single drink of water). For this reason, and also because at the individual observation level certain practices may be appropriate in certain CDRP environments and/or there may be path dependence, we see persistence over time. To the extent priorities are stable, those we measure in 2008 are a good proxy for those throughout the period.

Nonetheless, priorities are by no means fully stable. The correlations above are far from perfect. And when we asked current managers whether any priorities had changed

\footnotetext{
47 The only exception was the priority given dealing with managing conflicts over the use of funds.

48 Exact calculations are available from the authors on request. Doing these calculations was more complicated because some respondents had only one top priority, not two.
} 
over the previous year, $41 \%$ responded "yes." By far the most-common reasons given were that national or local priorities had changed. ${ }^{49}$ However, if, where priorities are not stable, the change is random or due to exogenous shocks (such as changed national or local government priorities are likely to be), our data on current priorities creates noise -at the extreme, we know nothing about past priorities from current ones -- making our results conservative. If one alternatively assumes a problemistic search-based model of priority change over time as discussed earlier - where people choose priorities at random until they find one that works to reduce crime -- this will also generate conservative results. Assume the longer an impactful practice is prioritized, the greater its effect on crime ${ }^{50}$ For CDRP's where the priority measured in our survey has an impact, these will be a mixture of those having used the practice for a long period and those adopting it only recently, meaning these current observations on average underreport the full impact of such priorities. By contrast, for practices with no impact, no period of use reduces crime. Assuming priorities change in response to failure, those at the end of the period still prioritizing non-impactful practices will have prioritized a series of such practices during the treatment period. Our results therefore underestimate the impact of priorities that reduce crime compared to those that do not, again making results conservative. ${ }^{51}$

However, there are other possibilities for priority change that may bias results, as opposed to making them conservative. One is the endogeneity problem discussed earlier.

\footnotetext{
49 These responses suggest that respondents in the first instance were thinking about "priorities" in terms of specific CDRP activities - such as when the Home Office began promoting police/probation surveillance of "prolific and persistent offenders" - rather than priorities in the sense of management approaches from our survey. It is hard to imagine, for example, that the central government started urging CDRP's to put more emphasis on building trust or following up on commitments partners made.

${ }^{50}$ Or alternatively that it takes a certain number of years for the practice to have an impact, after which there is no additional impact.

${ }^{51}$ We are grateful to Joshua Goodman for conversations about this issue.
} 
An additional problem is that trust building or power equalization may be more important early in a partnership's history, meaning that results for these practices based on current priority may underestimate their importance; indeed, one could argue that if these still need to be priorities a decade after a CDRP was established, it is a sign the partnership is in trouble. If this were true, this would bias coefficients for these practices based on our 2008 data downward. (High priority in 2008 means a partnership in trouble, which in turn might be caused by worse crime performance.) More broadly, some respondents might choose to prioritize a practice - say, information sharing or performance measurement out of a perception that the CDRP is performing poorly in that area, which might bias coefficients downward because it is not prioritization per se that reduces crime, but presence of the practice, and in some cases high prioritization might suggest low presence. If true, the size of the positive relationships we find would be conservative. We note that the coefficient for power sharing in our model is indeed generally negative, consistent with this worry, but that for trust building it is quite strongly positive - though perhaps absent a bias, the latter coefficient might be even higher. This suggests that, at best, prioritizing power sharing contributes less to improved crime performance than does trust building. To examine this further, we first calculated the change in the mean prioritization for trust building and power sharing over time. ${ }^{52}$ For both, it actually increased -- 0.2 unit for trust and 0.3 unit for power sharing (similar to a mean increase of 0.2 unit for all 15 practices together ${ }^{53}$ ). This is not consistent with the worry these would typically be higher priorities at the beginning of a partnership than later. However, we

\footnotetext{
52 We used all 30 first community safety managers and 203 current ones for whom we had data.

53 This is possible because the only constraint for respondents was that they couldn't list more than two practices as top priorities; respondents could if they wished list all other practices in the second-highest priority category. The mean prioritization for two of the practices decreased over time.
} 
also examined, for the 22 CDRP's where we had both-period observations, the correlation between change in crime and change in prioritization. For both cases, the correlation was negative (-.43 for power sharing and a weaker -.19 for trust building ${ }^{54}$ ) -for CDRP's increasing the priority given these practices, crime performance was worse than for those that hadn't. This is consistent with the suggestion that a CDRP that increases how much it prioritizes these practices is "in trouble.” We therefore would treat our negative coefficient for power sharing with caution.

Despite any limitations, we believe this study is a good first step in empirical research on the impact of management practices on collaboration success. If collaborative management is becoming as important as many argue, we will need more studies to develop paths we have begun to explore.

\footnotetext{
54 P-values were .39 and .05 respectively.
} 
1. building trust among partners (TRUST)

2. working hard to see to it that power is shared equitably in the Partnership (POWER SHARED)

3. communicating a vision of how partnership working can make our community safer. (VISION)

4. encouraging information sharing among partners (INFORMATION SHARING)

5. developing our own tailored initiatives, over and above central government initiatives (LOCAL INITIATIVES)

6. making sure there is follow-through on commitments partners make (FOLLOW-THROUGH)

7. dealing with blockages that are hurting the ability/willingness of partners to work together (BLOCKAGES)

8. implementing robust performance measurement/management (PERFORMANCE MEASUREMENT)

9. obtaining access to central government funds (ACCESSING MONEY)

10. pressing partners to commit more staff effort to partnership work (MORE STAFF)

11. obtaining or retaining strong support from the Chief Executive for community safety work (CHIEF EXECUTIVE)

12. resolving issues and conflicts about how central government funds are to be allocated among partner organizations and activities (MONEY CONFLICTS)

13. nurturing good relations with elected members (ELECTED OFFICIALS)

14. getting good media coverage for our initiatives (MEDIA)

15. nurturing good relations with the voluntary sector (VOLUNTARY SECTOR) 
TABLE 2: DESCRIPTIVE STATISTICS

\begin{tabular}{|c|c|c|c|c|}
\hline Variable & Mean & Std. dev. & Min & Max \\
\hline Trust & 3.9 & 0.8 & 2.0 & 5.0 \\
\hline Power Shared Equally & 2.9 & 0.8 & 1.0 & 5.0 \\
\hline Vision & 3.5 & 0.8 & 2.0 & 5.0 \\
\hline Information Sharing & 3.8 & 0.8 & 2.0 & 5.0 \\
\hline Local Initiatives & 3.6 & 0.7 & 2.0 & 5.0 \\
\hline Follow-Through & 3.7 & 0.7 & 2.0 & 5.0 \\
\hline Blockages & 3.8 & 0.9 & 2.0 & 5.0 \\
\hline Performance Measurement & 3.7 & 0.9 & 2.0 & 5.0 \\
\hline Accessing Money & 3.0 & 0.9 & 1.0 & 5.0 \\
\hline More Staff & 3.2 & 0.8 & 1.0 & 5.0 \\
\hline Chief Executive & 3.1 & 0.9 & 1.0 & 5.0 \\
\hline Money Conflicts & 3.0 & 0.9 & 1.0 & 5.0 \\
\hline Elected Officials & 3.2 & 0.7 & 2.0 & 5.0 \\
\hline Media & 3.4 & 0.8 & 1.0 & 5.0 \\
\hline Volunteer Sector & 3.0 & 0.6 & 1.0 & 4.0 \\
\hline logInitial Crime & -3.0 & 0.5 & -3.9 & -1.7 \\
\hline logPopulation & 11.7 & 0.6 & 7.7 & 13.8 \\
\hline Church Attendance & 6.4 & 2.2 & 3.0 & 19.0 \\
\hline Local Authority Performance & 2.6 & 0.9 & - & 4.0 \\
\hline Political Stability & 6.3 & 1.5 & 3.0 & 8.0 \\
\hline London & 0.1 & 0.3 & - & 1.0 \\
\hline Wales & 0.1 & 0.3 & - & 1.0 \\
\hline
\end{tabular}




\section{TABLE 3: RESULTS OF REGRESSION ANALYSIS FOR MANAGEMENT PRACTICES}

\section{Log 2008 Crime}

TRUST

POWER SHARED EQUALLY

VISION

INFORMATION SHARING

LOCAL INITIATIVES

FOLLOW-THROUGH

BLOCKAGES

PERFORMANCE MEASUREMENT

ACCESSING MONEY

MORE STAFF

CHIEF EXECUTIVE

MONEY CONFLICTS

ELECTED OFFICIALS

MEDIA

VOLUNTARY SECTOR

logINITIAL CRIME X ELECTED OFFICIALS

logPOPULATION X CHIEF EXECUTIVE

logPOPULATION X PERFORMANCE MEASURES

LOCAL AUTHORITY PERFORMANCE X BLOCKAGES

LOCAL AUTHORITY PERFORMANCE X PERFORMANCE MEASURES

LOCAL AUTHORITY PERFORMANCE X MEDIA

POLITICAL STABILITY X ACCESSING MONEY

\%MALE TEENS $X$ TRUST

\%MALE TEENS $X$ FOLLOW THROUGH

$\%$ MALE TEENS X MONEY CONFLICTS

$\%$ MALE TEENS X CHIEF EXECUTIVE

LONDON X POWER SHARED

LONDON X CHIEF EXECUTIVE

LONDON X MONEY CONFLICTS

LONDON X PERFORMANCE MEASURES

LONDON X VISION

WALES X INFO SHARING

WALES X POWER SHARED

WALES X CHIEF EXECUTIVE

WALES X LOCAL INITIATIVES

LOCAL AUTHORITY PERFORMANCE

POLITICAL STABILITY

$\%$ MALE TEENS

LONDON

WALES

CHURCH ATTENDANCE

logINITIAL CRIME

$\operatorname{logPOPULATION}$

CONSTANT
Coefficient $\quad \mathbf{P}>|\mathbf{t}|$

$0.012 \quad 0.39$

$\begin{array}{ll}-0.016 & 0.17\end{array}$

$-0.022 \quad 0.13$

$\begin{array}{ll}-0.002 & 0.86\end{array}$

$0.011 \quad 0.51$

$0.026 \quad 0.09$

$0.007 \quad 0.54$

$\begin{array}{ll}-0.0008 & 0.95\end{array}$

$\begin{array}{ll}-0.002 & 0.89\end{array}$

$\begin{array}{ll}-0.013 & 0.42\end{array}$

$0.008 \quad 0.62$

$\begin{array}{ll}-0.020 & 0.10\end{array}$

$0.021 \quad 0.23$

$0.010 \quad 0.49$

$\begin{array}{ll}-0.001 & 0.93\end{array}$

$0.051 \quad 0.06$

$0.039 \quad 0.09$

$0.050 \quad 0.02$

$0.034 \quad 0.006$

$0.021 \quad 0.05$

$0.042 \quad 0.000$

$0.025 \quad 0.005$

$0.060 \quad 0.05$

$0.038 \quad 0.07$

$\begin{array}{ll}-0.044 & 0.02\end{array}$

$\begin{array}{ll}-0.070 & 0.05\end{array}$

$0.167 \quad 0.000$

$\begin{array}{ll}-0.170 & 0.000\end{array}$

$0.064 \quad 0.009$

$\begin{array}{ll}-0.067 & 0.04\end{array}$

$0.153 \quad 0.000$

$-0.164 \quad 0.000$

$0.166 \quad 0.000$

$\begin{array}{ll}-0.061 & 0.01\end{array}$

$\begin{array}{ll}-0.136 & 0.002\end{array}$

$0.013 \quad 0.21$

$\begin{array}{ll}-0.002 & 0.69\end{array}$

$0.014 \quad 0.48$

$0.130 \quad 0.001$

$0.036 \quad 0.32$

$0.014 \quad 0.05$

$0.269 \quad 0.000$

$0.027 \quad 0.26$

$0.3472 \quad 0.308$

Number of obs $=203$

R-squared $=0.70$ 
TABLE 4: COEFFICIENTS FOR IMPACTS OF VARIABLES, WITH INTERACTIONS AT MEAN, ONE STANDARD DEVIATION ABOVE/BELOW MEAN

\begin{tabular}{|l|c|c|c|}
\hline & $\begin{array}{c}\text { At } \\
\text { 1 S.D. below mean }\end{array}$ & $\begin{array}{c}\text { At } \\
\text { Mean }\end{array}$ & $\begin{array}{c}\text { At } \\
\text { 1 S.D. above mean }\end{array}$ \\
\hline FOLLOW THROUGH & 0.004 & 0.026 & 0.048 \\
\hline BLOCKAGES & -0.024 & 0.007 & 0.038 \\
\hline PERFORMANCE MEASUREMENT (Outside London) & & & \\
\hline Local Authority Performance & -0.020 & -0.001 & 0.019 \\
\hline logPopulation & -0.029 & -0.001 & 0.028 \\
\hline ACCESSING MONEY & -0.040 & -0.002 & 0.036 \\
\hline CHIEF EXECUTIVE (Outside London \& Wales) & & & \\
\hline$\quad$ logPopulation & -0.015 & 0.008 & 0.030 \\
\hline \% Male Teens & 0.048 & 0.008 & -0.033 \\
\hline MONEY CONFLICTS (Outside London) & 0.006 & -0.020 & -0.046 \\
\hline TRUST & -0.023 & 0.012 & 0.047 \\
\hline ELECTED OFFICIALS & -0.002 & 0.021 & 0.044 \\
\hline MEDIA & -0.028 & 0.010 & 0.049 \\
\hline
\end{tabular}


TABLE 5: CDRP'S WITH POSITIVE SIGN FOR COEFFICIENT FOR TREATMENT

Trust

Power Shared Equally

Vision

Information Sharing

Local Initiatives

Follow-Through

Blockages

Performance Measurement

Accessing Money

More Staff

Chief Executive

Money Conflicts

Elected Officials

Media

Voluntary Sector

$\begin{array}{cc}\text { Proportion of CDRPs } & \text { Proportion of Population } \\ 72 \% & 77 \% \\ 16 \% & 19 \% \\ 7 \% & 11 \% \\ 0 . \% & 0 \% \\ 91 \% & 92 \% \\ 956 \% & 96 \% \\ 58 \% & 59 \% \\ 44 \% & 58 \% \\ 46 \% & 43 \% \\ 0 . \% & 0 \% \\ 53 \% & 61 \% \\ 13 \% & 15 \% \\ 81 \% & 88 \% \\ 58 \% & 59 \% \\ 0 . \% & 0 \%\end{array}$




\section{REFERENCES}

6, P., Leat, D., Seltzer, K. \& Stoker, G. 2002, Toward Holistic Governance: The New Reform Agenda, Palgrave, Houndmills, Basingstoke.

Abramson, M., Breul, J.D.B. \& Kamensky, J. 2006, Six Trends Transforming Government, IBM Business of Government Project, Washington, DC.

Agranoff, R. 2007, Managing within Networks: Adding Value to Public Organizations, Georgetown University Press, Washington, DC.

Agranoff, R. 2003, Leveraging Networks: A Guide for Public Managers Working across Organizations, IBM Endowment for The Business of Government, Washington, DC.

Agranoff, R. \& McGuire, M. 2003, Collaborative Public Management: New Strategies for Local Governments, Georgetown University Press, Washington, DC.

Agranoff, R. \& McGuire, M. 2001, "Big Questions in Public Network Management Research", Journal of Public Administration Research and Theory, vol. 11, no. 3, pp. 295-326.

Aiken, L.S. \& West, S.G. 1991, Multiple Regression: Testing and Interpreting Interactions, Sage, Thousand Oaks, CA.

Aiken, M.T., Dewar, R., DiTomaso, N., Hage, J. \& Zeitz, G. 1975, Coordinating human services, JosseyBass Publishers, San Francisco.

Alexander, J.A., Comfort, M.E., Weiner, B.J. \& Bogue, R. 2001, "Leadership in Collaborative Community Health Partnerships", Nonprofit Management \& Leadership, vol. 12, no. 2, pp. 159-175.

Alter, C. \& Hage, J. 1993, Organizations Working Together: Coordination in Interorganizational Networks, Sage Publications Inc, Newbury Park, CA.

Andrews, R. \& Entwistle, T. 2010, "Does Cross-Sectoral Partnership Deliver? An Empirical Exploration of Public Service Effectiveness, Efficiency, and Equity", Journal of Public Administration Research and Theory, vol. 20, no. July.

Andrews, R., Boyne, G.A., Law, J. \& Walker, R.M. 2005, "External Constraints on Local Service Standards: The Case of Comprehensive Performance Assessment in English Local Government", Public Administration, vol. 83, no. 3, pp. 639-656.

Audit Commission 2006, Briefing on the Audit Commission's Comprehensive Performance Assessment Frameworks: Local Government Briefing December 2006, UK Audit Commission, London.

Audit Commission 2003, Performance indicators 2002/03 Council services compendium for England, Audit Commission, London.

Bardach, E. 1998, Getting Agencies to Work Together: The Practice and Theory of Managerial Craftsmanship, Brookings Institution Press, Washington, DC.

Barr, C. \& Huxham, C. 1996, "Involving the Community: Collaboration for Community Development" in Creating Collaborative Advantage, ed. C. Huxham, Sage Publications Inc, London. 
Bazerman, M.H. \& moore, d. 2009, Judgment in Managerial Decision Making, 7th Ed. edn, John Wiley \& Sons, Inc., Hoboken, NJ.

BBC News 2009, June 7, 2009-last update, Elections 2001 - 2008 - Councils A-Z [Homepage of BBC], [Online]. Available: news.bbc.co.uk [2009, July 27, 2009] .

Behn, R.D. 2003, "Why Measure Performance? Different Purposes Require Different Measures", Public Administration Review, vol. 63, no. 5, pp. 586-606.

Benson, J.K. 1975, "The Inter-organizational Network as a Political Economy", Administrative Science Quarterly, vol. 20, no. June, pp. 229-249.

Blomgren Bingham, L., Sandfort, J. \& O'Leary, R. 2008, "Learning to Do and Doing to Learn: Teaching Managers to Collaborate in Networks" in Big Ideas in Collaborative Public Management, eds. L. Blomgren Bingham \& R. O'Leary, M. E. Sharpe, Inc, Armonk, NY, pp. 270-286.

Boulding, K.E. 1964, "A Pure Theory of Conflict Applied to Organizations" in The Frontiers of Management Psychology, ed. G. Fisk, Harper \& Row, New York.

Brewer, M.B. 1979, "In-group Bias in the Minimal Intergroup Situation: A Cognitive-Motivational Analysis", Psychological Bulletin, vol. 86, no. 2, pp. 307-324.

Bryson, J.M. \& Crosby, B.C. 2008, "Failing into Cross-Sector Collaboration Successfully" in Big Ideas in Collaborative Public Management, eds. L. Blomgren Bingham \& R. O'Leary, M. E. Sharpe, Inc, Armonk, NY, pp. 55-78.

Burns, J.M. 1978, Leadership Harper \& Row, New York.

Carley, M., Chapman, M., Hastings, A., Kirk, K. \& Young, R. 2000, Urban Regeneration through Partnership: A Study in Nine Urban Regions in England, Scotland, and Wales, The Policy Press and the Joseph Rowntree Foundation, Bristol, UK.

Chen, Bin. 2010, “Antecedents or Processes?: Determinants of Perceived effectiveness of Interorganizational Collaborations for Public Service Delivery”, International Public Management Journal, vol. 13, no. 4, pp.381-407.

Chrislip, D.D. \& Larson, C.E. 1994, Collaborative Leadership: How Citizens and Civic Leaders Can Make a Difference, Jossey-Bass Inc., San Francisco, CA.

Chung, S.A.:.S., H. \& Lee, K. 2000, "Complementarity, Status Similarity, and Social Capital as Drivers of Alliance Formation", Strategic Management Journal, vol. 21, pp. 1-22.

Crawford, A. 1997, The Local Governance of Crime: Appeals to Community and Partnerships, Clarendon Press, Oxford.

Cropper, S. 1996, "Collaborative working and the issue of sustainability" in Creating Collaborative Advantage, ed. C. Huxham, Sage Publications Inc, London, pp. 80-100.

Cropper, S., Ebers, M., Huxham, C. \& Smith Ring, P. (eds) 2008, The Oxford Handbook of Interorganizational Relations, Oxford University Press, Oxford.

Crosby, B.C. \& Bryson, J.M. 2005, "A Leadership Framework for Cross-Sector Collaboration", Public Management Review, vol. 7, no. 2, pp. 177-201. 
Cyert, R.M. \& March, J.G. 1963, Behavioral Theory of the Firm, Prentice Hall, Englewood Cliffs, NJ.

Efroymson, M.A. 1960, "Multiple Regression Analysis" in Mathematical Methods for Digital Computers, eds. A. Ralston \& H. Wilf, John Wiley \& Sons, New York.

Eungha Ryu, J. \& Rainey, H.G. 2009, "Collaborative Public Management and Organizational Design: Onestop Shopping Structures in Employment Training Programs" in The Collaborative Public Manager: New Ideas for the Twenty-first Century, eds. R. O'Leary \& L. Blomgren Bingham, Georgetown University Press, Washington, DC, pp. 177-194.

Farrell, M. 2009, Personal e-mail communication.

Fayol, H. 1949, General and industrial management, Pitman, London.

Feist, A. 2010, Personal E-mail Communication.

Freedman, J.L. \& Fraser, S.C. 1966, "Compliance Without Pressure: The Foot-in-the-Door Technique", Journal of Personality and Social Psychology, vol. 4, pp. 195-202.

Galbraith, J. 1973, Designing Complex Organizations, Addison-Wesley, Reading, MA.

Gans, S.P. \& Horton, G.T. 1975, Integration of Human Services: The State and Municipal Levels, Praeger Publishers, New York.

Geddes, M. 2008, "Inter-organizational Relationships in Local and Regional Development Partnerships" in The Oxford Handbook of Inter-organizational Relations, eds. S. Cropper, M. Ebers, C. Huxham \& P. Smith Ring, Oxford University Press, Oxford, pp. 203-230.

Gibbs, A. 2001, "Partnership Between the Probation Service and Voluntary Sector Organizations", British Journal of Social Work, vol. 31, pp. 15-27.

Glaeser, E.L., Laibson, D.I., Scheinkman, J.A. \& Soutter, C.L. 2000, "Measuring Trust", Quarterly Journal of Economics, vol. 115, no. 3, pp. 811-846.

Glendinning, C., Powell, M. \& Rummery, K. (eds) 2002, Partnerships, New Labour and the Governance of Welfare, The Policy Press, Bristol, UK.

Gray, B. 1989, Collaborating: Finding Common Ground for Multiparty Problems, Jossey-Bass Inc., San Francisco, CA.

Gray, B. \& Wood, D.J. 1991, "Collaborative Alliances: Moving from Practice to Theory", Journal of Applied Behavioral Science, vol. 27, no. 2, pp. 3-22.

Greene, W.H. 2007, Econometric Analysis, 6th Edition, Prentice Hall, Upper Saddle River, NJ.

Gulick, L.H. 1937, "Notes on the Theory of Organization" in Papers on the Science of Administration, eds. L.H. Gulick \& L.F. Urwick, Institute of Public Administration, Columbia University, New York, pp. 3-21.

Gulick, L.H. \& Urwick, L.F. 1937, Papers on the science of administration, Institute of Public Administration, Columbia University, New York.

Haass, R.N. 1994, The Power to Persuade, Houghton Mifflin, Boston. 
Hatry, H.P. \& Wholey, J.S. 1999, Performance Measurement: Getting Results, Urban Institute Press, Washington, DC.

Heymann, P.B. 1987, The Politics of Public Management, Yale University Press, New Haven, CT.

Hibbert, P., Huxham, C. \& Smith Ring, P. 2008, "Managing Collaborative Inter-organizational Relations" in The Oxford Handbook of Inter-organizational Relations, eds. S. Cropper, M. Ebers, C. Huxham \& P. Smith Ring, Oxford University Press, Oxford, pp. 390-416.

Home Office 2003, SR2002 Public Service Agreement Technical Notes, UK Home Office, London.

Horwitz, S.K. \& Horwitz, I.B. 2007, "The Effects of Team Diversity on Team Outcomes: A Meta-Analytic Review of Team Demography", Journal of Management, vol. 33, no. 6, pp. 987-1015.

Huxham, C. \& Vangen, S. 2005, Managing to Collaborate: The Theory and Practice of Collaborative Advantage, Routledge, Abingdon, Oxon.

Ingraham, P.W., Joyce, P.G. \& Donahue, A.K. 2003, Government Performance: Why Management Matters, Johns Hopkins University Press, Baltimore, MD.

Jennings, E.T., Jr. \& Ewalt, J.A.G. 1998, "Interorganizational Coordination, Administrative Consolidation, and Policy Performance", Public Administration Review, vol. 58, no. 5, pp. 417-428.

Keast, R. \& Brown, K. 2002, "The Government Service Delivery Project: A Case Study of the Push and Pull of Central Government Coordination", Public Management Review, vol. 4, no. 4, pp. 439-459.

Kelman, S.J. 2006, "Book Review Essay: 9/11 and the Challenges of Public Management: The 9/11 Commission Report: Final Report of the National Commission on Terrorist Attacks upon the United States. National Commission on Terrorist Attacks.", Administrative Science Quarterly, vol. 51, no. 1, pp. 129-142.

Kettl, D. 2008, The Next Government of the United States, Norton, New York.

Klijn, E. 2008, "Policy and Implementation Networks: Managing Complex Interactions" in The Oxford Handbook of Inter-organizational Relations, eds. S. Cropper, M. Ebers, C. Huxham \& P. Smith Ring, Oxford University Press, Oxford, pp. 118-146.

Koontz, T.M. \& Thomas, C.W. 2006, "What Do We Know and Need to Know about the Environmental Outcomes of Collaborative Management?", Public Administration Review, vol. 66, no. s1 (December - Special Issue), pp. 111-121.

Kotter, J.P. 1990, A Force for Change: How Leadership Differs from Management, The Free Press, New York.

Lasker, R.D., Weiss, E.S. \& Miller, M., Rebecca 2001, "Partnership Synergy: A Practical Framework for Studying and Strengthening the Collaborative Advantace", The Milbank Quarterly, vol. 79, no. 2, pp. 179-205.

Lee, M. 1998, Youth, Crime and Police Work, St. Martin's Press, Inc., New York.

Levin, M.A. \& Sanger, M.B. 1994, Making Government Work: How Entrepreneurial Executives Turn Bright Ideas into Real Results, Jossey-Bass Inc., San Francisco, CA. 
Levine, S. \& White, P.E. 1961, "Exchange as a Conceptual Framework for the Study of Interorganizational Relationships", Administrative Science Quarterly, vol. 5, no. 4, pp. 583-601.

Light, R.J., Singer, J.D. \& Willett, J.B. 1990, By design : planning research on higher education, Harvard University Press, Cambridge, Mass.

Linden, R.M. 2002, Working Across Boundaries: Making Collaboration Work in Government and Nonprofit Organizations, John Wiley \& Sons, San Francisco.

Ling, T. 2002, "Delivering joined-up government in the UK: dimensions, issues and problems", Public Administration, vol. 80, no. 4, pp. 615-642.

Linsky, M. 1986, Impact: How the Press Affects Federal Policymaking, W.W. Norton \& Co., New York.

Litwak, E. \& Hylton, L.F. 1962, "Interorganizational Analysis: A Hypothesis on Co-ordinating Agencies", Administrative Science Quarterly, vol. 6, no. 4, pp. 395-420.

Litwak, E. \& Rothman, J. 1970, "Towards the Theory and Practice of Coordination Between Formal Organizations" in Organizations and Clients: Essays in the Sociology of Service, eds. W.R. Rosengren \& M. Lefton, Charles E. Merrill Publishing Co., Columbus, OH.

Lowndes, V. \& Skelcher, C. 2002, "The Dynamics of Multi-organizational Partnerships: An Analysis of Changing Modes of Governance", Public Administration, vol. 76, no. 2, pp. 313-333.

Lynn, L.E., Jr., Carolyn J. Heinrich, Carolyn J. \& Hill, C.J. 2000, "

Studying Governance and Public Management: Why? How?" in Governance and Performance: New Perspectives, eds. C.J. Heinrich \& S.J. Carroll, Georgetown University Press, Washington DC, pp. 234.

McGuire, M. 2006, "Collaborative public management: Assessing what we know and how we know it", Public administration review, vol. 66, no. s1, pp. 33-43.

McGuire, M. 2009, "The New Professionalism and Collaborative Activity in Local Emergency Management" in The Collaborative Public Manager: New Ideas for the Twenty-first Century, eds. R. O'Leary \& L. Blomgren Bingham, Georgetown University Press, Washington, DC, pp. 71-94.

McGuire, M. 2003, "Is It Really So Strange? A Critical Look at the 'Network Management is Different from Hierarchical Management' Perspective", Seventh National Public Management Research Conference.

McGuire, M. \& Silvia, C. 2009, "Does Leadership in Networks Matter? Examining the Effect of Leadership Behaviors on Managers' Perceptions of Network Effectiveness", Public Performance \& Management Review, vol. 33, no. 1, pp. 34-62.

Menard, S. Applied Logistic Regression Analysis, Sage, Thousand Oaks, CA.

Milward, H.B. \& Provan, K.G. 2006, A Manager's Guide to Choosing and Using Collaborative Networks, IBM Center for The Business of Government.

Minkes, J., Hammersley, R. \& Raynor, P. 2005, "Partnership Working with Young Offenders with Substance Misuse Problems", The Howard Journal, vol. 44, no. 3, pp. 254-268.

Mintzberg, H. 1973, The Nature of Managerial Work, Harper \& Row, New York. 
Mitchell, S.M. \& Shortell, S.M. 2000, "The Governance and Management of Effective Community Health Partnerships: A Typology for Research, Policy, and Practice", The Milbank Quarterly, vol. 78, no. 2, pp. 241-289.

Moore, M.H. 1995, Creating Public Value: Strategic Management in Government, Harvard University Press, Cambridge, MA.

Moynihan, D.P. 2008, The Dynamics of Performance Management: Constructing Information and Reform, Georgetown University Press, Washington, DC.

Moynihan, D.P. 2005, Leveraging Collaborative Networks in Infrequent Emergency Situations, IBM Center for the Business of Government, Washington, DC.

Moynihan, D.P. \& Pandey, S.K. 2005, "Testing How Management Matters in an Era of Government by Performance Management", Journal of Public Administration Research and Theory, vol. 15, no. 3, pp. 421-439.

Nash, M. 2004, "Probation and Community Penalties" in , eds. J. Muncie \& D. Wilson, Cavendish Publishing Limited, London, pp. 235-248.

Newspaper Society , NS Database: Newspaper Reports [Homepage of The NS and AdWeb Limited], [Online]. Available: http://www.nsdatabase.co.uk/ [2010, 05/28] .

Nowell, B. 2009; 2010, "Out of Sync and Unaware? Exploring the Effects of Problem Frame Alignment and Discordance in Community Collaboratives ", Journal of Public Administration Research and Theory, vol. 20, no. 1, pp. $91<$ last_page> 116.

O'Leary, R., Gazley, B., McGuire, M. \& Blomgren Bingham, L. 2009, "Public Managers in Collaboration" in The Collaborative Public Manager: New Ideas for the Twenty-first Century, eds. R. O'Leary \& L. Blomgren Bingham, Georgetown University Press, Washington, DC, pp. 1-12.

Oliver, C. 1990, "Determinants of Inter-organizational Relationships: Integration and Future Directions", Academy of Management Review, vol. 15, no. 2, pp. 241-265.

O'Toole, Laurence J. , Jr. \& Meier, K.J. 2003, "Plus ca Change: Public Management, Personnel Stability, and Organizational Stability", Journal of Public Administration Research and Theory, vol. 13, no. 1, pp. 43-64.

Page, S. 2008, "Managing for Results Across Agencies: Building Collaborative Capacity in the Human Services" in Big Ideas in Collaborative Public Management, eds. L. Blomgren Bingham \& R. O'Leary, M. E. Sharpe, Inc, Armonk, NY, pp. 138-161.

Page, S. 2003, "Entrepreneurial Strategies for Managing Interagency Collaboration", Journal of Public Administration Research and Theory, vol. 13, no. 3, pp. 311-340.

Payne, J.L. 1980, "Show horses \& work horses in the United States House of Representatives", Polity, vol. 12, no. 3, pp. 428-456.

Phillips, C. 2002, "From Voluntary to Statutory Status: Reflecting on the experience of three partnerships established under the Crime and Disorder Act of 1998" in Crime Prevention and Community Safety: New Directions, eds. G. Hughes, E. McLaughlin \& J. Muncie, Sage Publications, London, pp. 166181. 
Pollitt, C. 2003, The Essential Public Manager, Open University Press, Maidenhead, Berkshire, UK.

Powell, W.W. 1990, "Neither Market Nor Hierarchy: Network Forms of Organization", Research in Organizational Behavior, vol. 12, pp. 295-336.

Provan, K.G. \& Kenis, P. 2008, "Modes of Network Governance", Journal of Public Administration Research and Theory, vol. 18, no. 2, pp. 229-252.

Provan, K.G., Kenis, P. \& Human, S.E. 2008, "Legitimacy Building in Organizational Networks" in Big Ideas in Collaborative Public Management, eds. L. Blomgren Bingham \& R. O'Leary, M. E. Sharpe, Inc, Armonk, NY, pp. 121-137.

Provan, K.G. \& Sydow, J. 2008, "Evaluating Inter-organizational Relationships" in The Oxford Handbook of Inter-organizational Relations, eds. S. Cropper, M. Ebers, C. Huxham \& P. Smith Ring, pp. 691710.

Provan, K.G. \& Milward, H.B. 1995, "A Preliminary Theory of Interorganizational Network Effectiveness: A Comparative Study of Four Community Mental Health Systems", Administrative Science Quarterly, vol. 40, no. 1, pp. 7-23.

Putnam, R.D. 2007, "E Pluribus Unum : Diversity and Community in the Twenty-first Century The 2006 Johan Skytte Prize Lecture", Scandinavian Political Studies, vol. 30, no. 2.

Putnam, R.D. \& Campbell, D.E. 2010, American Grace: How Religion Divides and Unites Us, Simon \& Schuster, New York.

Rodriguez, C., Langley, A., Beland, F. \& Denis, J. 2007, "Governance, Power, and Mandated Collaboration in an Interorganizational Network", Administration \& Society, vol. 39, no. 2, pp. 150 193.

Rosenbaum, D.P. 2002, "Evaluating multi-agency anti-crime partnerships: Theory, design, and measurement issues", Crime prevention studies, vol. 14, pp. 171-225.

Rowe, M. \& Devanney, C. 2003, "Partnership and the Governance of Regeneration", Critical Social Policy, vol. 23, no. 3, pp. $375<$ last_page $>397$.

Sandfort, J. \& Milward, H.B. 2008, "Collaborative Service Provision in the Public Sector" in The Oxford Handbook of Inter-organizational Relations, eds. S. Cropper, M. Ebers, C. Huxham \& P. Smith Ring, pp. 147-174.

Schermerhorn, J.R. 1975, "Determinants of Interorganizational Cooperation", The Academy of Management Journal, vol. 18, no. 4, pp. 846-856.

Selden, S.C., Sowa, J.E. \& Sandfort, J. 2006, "The Impact of Nonprofit Collaboration in Early Child Care and Education on Management and Program Outcomes", Public Administration Review, vol. 66, no. 3, pp. 412-425.

Sherif, M., Harvey, O.J., White, B.J., Hood, W.R. \& Sherif, C.W. 1961, Intergroup Conflict and Cooperation: The Robbers Cave experiment, University Book Exchange, Norman, OK.

Shortell, S.M., Zukoski, A.P., Alexander, J.A., Bazzoli, G.J., Conrad, D.A., Hasnain-Wynia, R., Sofaer, S., Chan, B.Y., Casey, E. \& Margolin, F.S. 2002, "Evaluating Partnerships for Community Health 
Improvement: Tracking the Footprints", Journal of Health Politics, Policy and Law, vol. 27, no. 1, pp. 49-91.

Silvia, C. \& McGuire, M. 2010, "Leading Public Sector Networks: An Empirical Examination of Integrative Leadership Behaviors", The Leadership Quarterly, vol. 21, pp. 264-277.

Simmons, J., Legg, C. \& Hosking, R. 2003, National Crime Recording Standard (NCRS): an Analysis of the Impact on Recorded Crime. Companion Volume to Crime in England and Wales 2002/2003., UK Home Office, London.

Simmons, J., Legg, C. \& Hosking, R. 2003, National Crime Recording Standard (NCRS): An Analysis of the Impact on Recorded Crime - Part 2: Impact on Individual Police Forces. , UK Home Office, London.

Skogan, W.G. \& Hartnett, S.M. 1997, Community Policing, Chicago Style, Oxford University Press, Oxford.

Smith, K.G., Carroll, S.J. \& Ashford, S.J. 1995, "Intra- and Interorganizational Cooperation: Toward a Research Agenda", Academy of Management Journal, vol. 38, no. 1, pp. 7-23.

Stinchcombe, A.L. 1990, Information and Organizations, University of California Press, Berkeley, CA.

Sullivan, H. \& Skelcher, C. 2002, Working Across Boundaries: Collaboration in Public Services, Palgrave Macmillan, Houndmills, Basingstoke.

Tajfel, H., Billig, M.G., Bundy, R.P. \& Flament, C. 1971, "Social Categorization and Intergroup Behavior", European Journal of Social Psychology, vol. 1, no. 2, pp. 149-178.

Thacher, D. 2001, "Conflicting values in community policing", Law and Society Review, vol. 35, no. 4, pp. 765-798.

Thacher, D. 2004, "Interorganizational Partnerships as Inchoate Hierarchies: A Case Study of the Community Security Initiative", Administration \& Society, vol. 36, no. 1, pp. 91-127.

Thomas, C.W. 2003, Bureaucratic Landscapes: Interagency Cooperation and the Preservation of Biodiversity, The MIT Press, Cambridge, MA.

Thomson, A.M., Perry, J.L. \& Miller, T.K. 2008, "Linking Collaboration Processes and Outcomes: Foundations for Advancing Empirical Theory" in Big Ideas in Collaborative Public Management, eds. L. Blomgren Bingham \& R. O'Leary, M. E. Sharpe, Inc, Armonk, NY, pp. 97-120.

Tilley, N. 2002, Evaluation for crime prevention, Criminal Justice Press, Devon, UK.

Turner, J.C., Hogg, M. \& et al. 1987, Rediscovering the Social Group: A Self-Categorization Theory, Basil Blackwell, Oxford, UK ;New York, NY, USA.

Tyler, T.R. 1990, Why people obey the law, Yale University Press, New Haven, CT.

Van de Ven, Andrew H. 1976, "On the Nature, Formation, and Maintenance of Relations among Organizations", The Academy of Management Review, vol. 1, no. 4, pp. 24-36. 
Vangen, S. \& Huxham, C. 2003, "Enacting Leadership for Collaborative Advantage: Dilemmas of Ideology and Pragmatism in the Activities of Partnership Managers", British Journal of Management, vol. 14, pp. S61-S76.

Weiss, J.A. 1981, "Substance vs. Symbol in Administrative Reform: The Case of Human Services Coordination", Policy Analysis, vol. 7, no. 1, pp. 21-45.

Weiss, J.A. 1987, "Pathways to Cooperation among Public Agencies", Journal of Policy Analysis and Management, vol. 7, no. 1, pp. 94-117.

Williamson, O.E. 1975, Markets and Hierarchies: Analysis and Antitrust Implications, The Free Press, New York, NY.

Wilson, D. \& Game, C. 2006, Local Government in the United Kingdom, 4th Edition edn, Palgrave Macmillan, Houndsmills, Basingstoke, Hampshire.

Zegart, A.B. 2009, Spying Blind: The CIA, the FBI, and the Origins of 9/11, $1<$ Feature> ISBN13: $9780691141039<$ Feature $>$ Condition: NEW <Feature $>$ Notes: Brand New from Publisher. No Remainder Mark. edn, Princeton University Press, Princeton, N.J.

Zimring, F.E. 2007, The Great American Crime Decline, Oxford University Press, New York. 